University of Rhode Island

DigitalCommons@URI

Open Access Master's Theses

1973

\title{
The Third Man Argument and Its Role in Plato's Philosophy
}

Virginia E. Reaves

University of Rhode Island

Follow this and additional works at: https://digitalcommons.uri.edu/theses

\section{Recommended Citation}

Reaves, Virginia E., "The Third Man Argument and Its Role in Plato's Philosophy" (1973). Open Access Master's Theses. Paper 1539.

https://digitalcommons.uri.edu/theses/1539

This Thesis is brought to you for free and open access by DigitalCommons@URI. It has been accepted for inclusion in Open Access Master's Theses by an authorized administrator of DigitalCommons@URI. For more information, please contact digitalcommons-group@uri.edu. 


\section{B395 $R 42$}

THE THIRD MAN ARGUMENT

AND

ITS ROLE IN PIATO'S PHILOSOPHY

BY

VIRGINIA E. REAVES

A TEESIS SUBMITTED IN PARTIAL FULFILLMENT OF THE REQUIREYENTS FOR THE DEGREE OP

MASTER OF ARTS

IN

PEILOSOPHY

UNIVEESITY OF RHODE ISLAND

1973 
THE THIRD MAN ARGUMENT

AND

ITS ROLE IN PIATO'S PHILOSOPHY

An Abstract

The Third Man Argurent, which made its first

recorded appearance in the philosophy of anclent Greece, has most often been thought of as an attack upon Plato's Theory of Forms. Plato's theory, of course, accommodated two types of 'man': the Forr and the particular. The Form was that which two or more particular men were sald to be like one another 'In virtue of.' Plato had sought to restore the notion of stability in a world of apparent flux. Forms were anchanging, perfect, and independent. Particulars were changing, Imperfect, and dependent upon the Forms for their being. The Third Man Argument (actually there aro three versions--two pointins out a 'third man' In addition to the Form and particular, and one jlelding not only a 'third man.' but an indefinite number) attempts to show a flaw in Plato's Theory of Forms. What is indeed strange is the fact that plato presents the argument himself in his dialogue the Farmenides and seemingly leaves it unanswered. This has led compentators to a host of interpretations, pronouncing the argument 
elther valid or invalid, finding its role in Plato:s development elther signfficant or inalgnificant.

It is the purpose of this study to analyze the varlous versions of the Third Man Argument, to examine commentaries on them, to judge the validity of the arguments and their slgnificance to Plato's philosophy. It 18 my finding that Plato was certainly aware of the argument he was presenting--that he was actually using it to purge his followers of false notions of his theory arising, apparently, from taking his metaphorlaal language too 11terally. That he was aware of the difflculty of finding the right words, is seen, I think, in his dialogue Cratylus, It is my contention, hovever, that Plato knew the argument was valid (although not against his actual theory) and goes on in the Parmenides to set his followers straigint--presenting a dialectlcal exercise (far from being a 'Joke' as some have supposed) showing the necessity of certain combinations of Forms and Indirectly implying that the Th1rd Man Argument can be answered. Further it is possible that Plato had attempted to forestall a 'third man' as early as the Reoublic (w1th the now-famous Third Bed Argument\}. And with more technical terminology of recent times (ia R. E. Allen). 1dentifylng Forms as 'exemolary causes' and particulars 
as 'relational entitiea," I think that Plato's theory can be understood in such a way to hinder the entrance of any 'third man.' But the role that the Third Man Argument plays in Plato's philosophy is not so much a step in his development as it is a step to forestall others from developing his theory into something it was never intended to be. 


\section{ACKNOWLEDGMENTS}

First I wsh to thank Dr. John Peterson, my thesis directer, for his continuing inspiration, suggestions, and patience throughout the writing of this thesis. Second I wish to thank Dr. Standford Cashdollar for an enormous collection of materials I might otherwlse never have come across. Thirdiy, I thank Dr. Donald Zeyl, a latecomer to my thesis comittee, for his installments of suggestions, including the offer of some of his ow translations; had I known him earlier, his enfluence wight heve been greater. Last, but not least, I w1sh to thank Dr. John Hanke and Dr. H1111am Young for allowing me to venture on as I saw f1t. 
COMTENTS

I. APPROACH TO AND BACKGROUND OF THE THIRD MAN • - 1

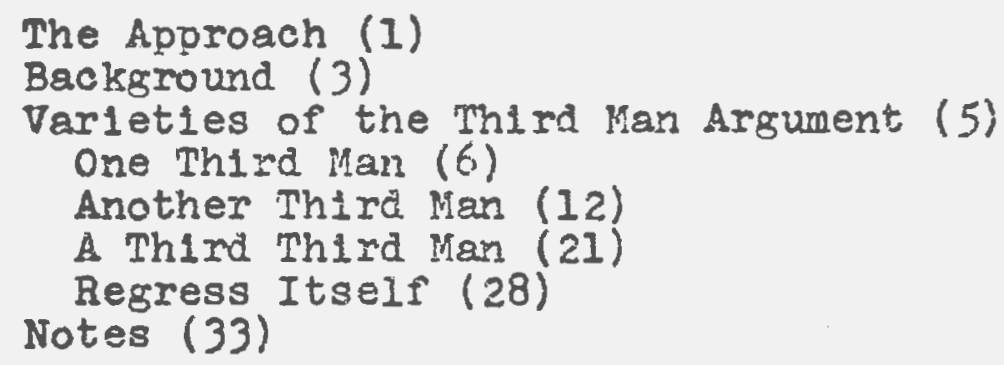

II. THE THIRD MAN IN THE PARMENIDES . . . . . 38

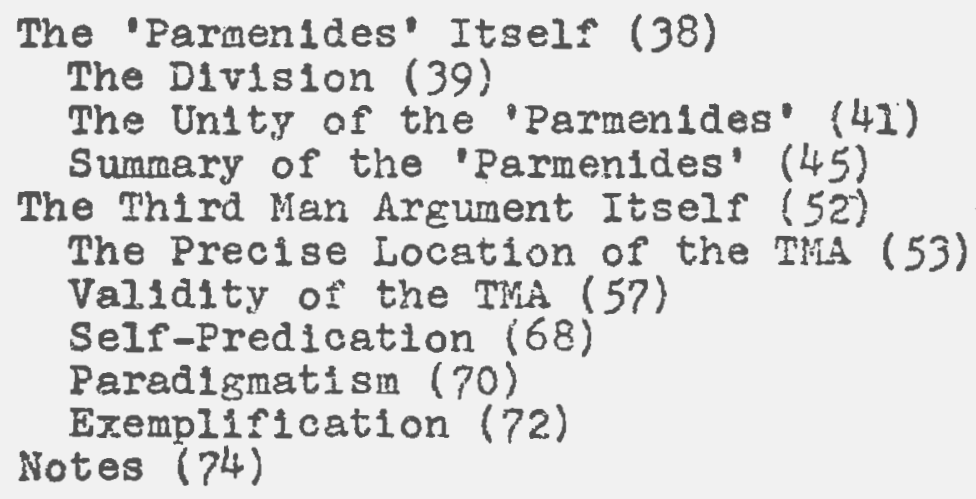

III. ESCAPING THE THIRD MANT . . . . . . . 80

The Relation and the Related (80)

The second Part of the "Parmenides" (94)

The Essertial Bed (102)

Why Socrates DIdn't Escape (107)

Notes (113)

SOURCES CONSULTED ........................ 116 
I

APPROACG TO AND BACKGROUND OF THE THIRD MAN

\section{The Approach}

Getting to the crux of tine so-called "Thirg Man Argument' and its role in Plato's philosophy is simllar to attempting to traverse Zeno of Elea's Line of Dlchotomy. whlch for my own purposes I choose tc map out in

a stadium, 1 before one can even get to center-stage one must flrst cover half the distance, and before reaching the half, half of the half, and before half of the half, half of the half of the half, and so on into infinity w1 thout ever reaching one's destination. Desplte many difficulties, It is the purpose of this paper to ezamine the Third Man Argument--1ts varlous versions (especially the one found in Plato's Parmenides), what it is almed against, whether or not it is valid, whether or not plato thought 1t was, whether or not Plato g170s an answer. and, finaliy, the use plato made of $1 t^{2}$

Much has been written on the subject yet controversy rewalns, and, w1ll remain, no doubt, arter.my thesis. I an by no means presenting the definitivs work on the Third Man. I am, however, bringing togetiner great bulk of the material alroady written and prasenting a 
possible interpretation of ny own--hoping that the response that 1t brings w11l elther reinforce it or completely demollsh 1t. Too much has been sald on the Third Man without sufficient explanation or rebuttal, I bring some of these views to light.

It 18 m contention that although the "Third Man' attempts varlous ways of entering into Plato's Theory of Forms to disrupt 1t, all attempts fall. It 1s, nonetheless, important, I think, in that it serves as an example of what happens when one takes Plato's theory (as presented in the Repub11c and the Phaedo) too I1terally and adds to 1 t ones ow contamination with appearances. Language belng but an imperfect copy together with man's inability to completely escape appearences is representative of the humen predicament, bound in the cave of appearances, knowing, perhaps, that real1ty lies outside, but having little ab1lity to find 1t--and eren if one does, the inab1lity to express $1 t$. Sheer ignorance or the fear of the unknom may lead some to postulate a "third man," hoping to make appearances sare as the only reality. The argument works, however, oniy as long as appearances creep in; Plato's theory of reality is not accurately presented in the argument and therefore the argument is not val1d against what it proposes to be against. Plato's doctrine, far from 
being simple, is complex, and the Third Man Argument, no matter what sect orfginated $1 t, 1$ used by Plato as a diuretic for his students--to purge them from an over-simplified view of h1s theory, to show them where problems of language and appearance might lead.

\section{Background}

The Third Man Argument made its first recorded appearanoe in ancient Greece and 18 most often thought of as an attack upon Plato's Theory of Forms. Plato's theory states that what we experlence are only resemblances of what really $18^{3}$--that particular men, for example, 'participate' in some Form Man, 4 Form Man belng that man, most real, whlch two or more men are 11 ke each other or sald to be man in virtue of. .5 The world of Forms 18 the real world, the absolute, the world of our senses 18 only the world of shadows, the relative. The Forms are unchanging and porfect, servIng as. the causes of things and as the criteria for knowledge. 6 We recognise particular things by recollecting the Forms and we are able to judge these particulars in light of the true Forms. As particular men we only approxlmate the real, unlque Form Man, we are mere resemblances.

The Third Man Argument (or at least the main version of $1 t$ ) attacks this point of resemblance and the notion 
of some 'unique' Form over a group of nany particulars. Forms appear as belng separate from particulars, yet it 18. what these particulars hold in common. But suppose you go a step further, do both the Form wan and the particular men have the characteristic 'man'? If the answer is affirmative, you are on the road to unlting the partioular man (Man I) along with the Form Man (Man II) with some additional Form Man (Man III) coming over and above the other two. Th1s road leads not only to some 'third man' but to an infinite number of men (Forms 'Man' wich denies Plato's thesis that each Form is unique, that 1s, there is just one Form Man, one Form Bed, etc. 7 If the Third Man Argument is in fact logically valid, If it is agalngt what Plato actually held, and if Plato has not managed an escape route, it just might be possible that his metaphysics, epistemology, snd ethics are in for serious trouble. What 18 surprising is this Plato himself implies another version of this argument and directly presents the one given above in the Parmen1des. One would think after becoming familiar with the wide range of commentaries on the parmenides and the numerous different reasons for the 'third man' appearing therein, that Plato wrote his dialogues so that anything could be deduceable from his texts. Actually. I flnd. that Plato is not perfestly clear, and if one does not go beyond appearances, one might well conclude that his 
philosophy is full of contradictions. Does Plato think that the 'third man' 18 an intruder to be dealt with and 1f so, for what raason? Is the argument val1d and is Plato forced to replse or abolish his theory? Does the second part of the Parmenides actually bring an answer to the Third Man--or 18 that part of the dialogue only a joke? Does Plato st1ll speak of the Forms in h1s later dialogues in the same way as in earlier ones? These questions and many more have been met with contrary answers by Flato scholars. But before taking on this 'third man' and his role in Plato's thought, it is important to note that there are at least two other versions of the Third Man Argument.

\section{Varleties of the Third Man Argument}

As 11 the problem of regress in the TMA $18 n^{\circ} t$ enough, there were two other Third Man Arguments going around about the time of the one mentioned--both desiring to add some 'third man' to man the particular and man the Form--but thes time without any regress. Now, exactly phat these arguments are and what they are against seems like something whlch needs considering, and to proceed In a secure and orderly path it might be well to glve all three Third Wen Argurants. Alexander of Aphrodisias recorded the three varicus arguments in his commentary. on Aristotle's Metaphysics (Met. a. 990b 15). 8 The 
third rersion is expressed in two parts and although

Alexander presents the first part by way of introduction to his comments. I shall reserve it for after the second version of the argument.

One Third Man

This first Third Man 18 ascribed to the Megarian logicians (sophlsts) generally, Alexander states 1t:

If พе say 'there is a man walking' we do not mean that Man, in the sense of the Form is walking--for the Form is unmoving--nor jet a determinate particular man--and how can we mean this if we do not recognise the man? We are aware that a man is walking, but not who the particuiar man 15 of whom we asswert this, we are saying that another third man different from these is walking. Ergo, there is a third man of whom we have predlcated that he is walking. To be sure, this argument 18 sophistical but an opening 18 made for it by those who postulate the Forms. 9

Th1s argument has been commonly interpreted as belng based on the amblguity resulting from lack of an inderinite article (there belng none in Greek). Such commentators as A. E. Taylor and Franc1s M. Cornford ${ }^{10}$ hold this view, and simply by looking at the argument, their interpretation seems quite plausible.

I might saj, for example, that a man is walking by the Phllosophy Department door. Nor, plainly I do not mean that the Form Man is walking by because, according to Plato, Forms do not move and are not oapable of belng snatched (this man is moring and I mlght verg well snatch 
him up and pull him into the of $100--2$ good catch if Indeed he be the Form--philosophiosily rewarding:); surely, too, if the man keeps walking and escapes down the steps and out the door. I would not in tears cry out, "Oh, dear, there goes Bumanlty:" But st1ll it remains that $I$ do not know who the man 18 ; he is no specific fellow that I know. So if he is not some speciflc particular or the unique Form, what or who is he? The answer seems to ber he is some unspecifled particular. If I were to obtain names of every man well perserved enough to walk and place them all in a disjunctive proposition ("E1ther Chalrman Freeman reiled by or Dr. Young walked by or Dr. Martin walked by or Dr. Peterson walked by or ...."), then I mean that some one of this set hes just walked by--but eractly which I do not know. The man, ther, is a particular, partaking of the Form Man and surely not sometring over and above the Form. There is no infintte regress and 15 taken this way poses no threat to Plato's Theory of Forms. As Taylor concludes, ". . It is merely a correct reflection on the ambiguity of the article such as would naturally occur to anjone interested in the formal development of log1c." 11

If, however, one says $81 \mathrm{mplg}$ "man walks" Instead of "a man is walking" "man' in this case without the articlo 
28 the Greek would allow, then something queer does heppen. Harold Chernisa contends that this is how the argument is meant to be taicen since wisy else would a Megarlan group come up with it and why else would an Inderinlte subject be called a "third man'? Cherniss supposes that the argument polnts to Plato's Theorg of Forms ana 1 ts inability to account for common predicates. He says that the subject is not some particular man but rather it is not any particular man. The man who walks by the Ph1losophy Department door 18 not a Form and not a particular, he is just a man. To saj that man walks 8 uggests a common prodicate 'man'--certalniy nelther Form nor particular--but a "th1rd $\operatorname{man}^{\prime}$; hence, as Chern1ss would have 1t, we rould have three types of 'man', Man the Form, man the partloular, and man the common predicate. When we say "man waiks" we are speaking of men in genoral. 12 The Form is not 'men in general' for Plato, certainly; it is what 18 most truly real, a substance, and we are only relational ent1ties 13 having a sort of adjectivel existence. E. E. Allen, who also holds this latter view, finds that the fallure to account for common predicates 18 not so much en oversight on Plato's part but rather the consequence of h1s ontology. In fact. Allen contends that Plato's Forms are actually the causes of particulars, exomplary causes. 
All statements of the form ". . 18 F" are e1ther statements of 1dentity or relational atatements. ${ }^{14}$ In the case of the latter.". . Is F" 18 to be interpreted as "F is the cause of . ."15. A varlety of different Forms cause us to be the way we are, as we are, In this world of Becoming. Ontologically there is no need for common predicates, and with no such predicates no third man can arise.

Just because we use a subject-predicate sentence structure is no reason to belleve that reality must correspond accordingls. In the Cratylus Plato shows that language is not perfect, I1ke everything else in this world of flux it 13 onis an approximation (perhaps, eren better, a distortion) of the truly real. Language, unfortunately, got off to a bad start. Those who inltiated 1t were spinning about so very much that their creation lacked the stabllity needed. Names and verbs were often misgiven without much thought. ${ }^{16}$ To crsate a closer approximation to the 1deal Language at this point wowld be futile and so Plato is lest to work with the subject-predicate struoture. Prodicates as wo know them (to affirm as a quality or attribute of something) are out of place in Plato's philosophy (what we call 'quallties' or 'attributes' are really substance and not something predicated of $1 t$ ). Look, for erample, 
at Plato's discussion of the virtues in the Protagoras (which, by the way, was uritten prior to the Phaedo where Plato argues extensively for the Forms, prior to the Permenides where ho seems to argue so strongly against them, and far earlier than the Soph1st where most commentators think the combining of Forms appoars for the first time). At 3318 Plato says "Justice 18 plous" and at 330D "Plety is just", he says "W1sdom is Courage" at $350 C$ and "Courage 18 W1sdom" at 361B. Now surely Justice is not the same Form as P1ety, and W1sdom is not the same Form as Courage. What is meant can, I think, be expleined in this way, Plety causes Justice and Justice causes Plety, Courage causes W1sdom and W18dom causes Courage. Courage is one of those things needed to make (cause) W1sdom to be what 1 t 13 . It 18 ne1ther '1dentical to' nor 'an attribute of.' 'Cause,' however, does not appear here in the exenplary sense as Allen shows the Forms to be of the sensible world; 17 it is a necessary cause-Courage is part of the essence of W18dom. I do not think that J.A. Ackrill is entirely incorrect in pointing out non-symmetrical relationships in the warld of Forms. I agree with him that Justice is a species of virtue, wherees V1rtue 18 not a species of Justice-mone clearly comes under the other, however, I am saying this: W1sdom, Courage, Just1ce, and 
Temperance may all be virtuss-entering into what Virtue 18--but then again Virtie combines with each of the others to make the others what they are. 18 The same holds true for "man walks", the Form Man certainly does not walk-Walk 18 not an attribute of the Form Man; it 18 part of Its essence. 19 Plato would $11 \mathrm{kely}$ take this as another example of the ability of certain Forns to combine. The Form Man combines with the Form Walk, whereas, it does not combine with the Form Fly (the Form Bird would combine with the Form Fly). Since this community of Forms is necessary. It is possible for resemblances of the Form Man to partake not only of that Form but also the Form Walk. In our oommon everyday language we might say "It 18 the nature of men to walk, say, rather than Ply." That 18 to 8ay, In Plato's language, that the Form Man does not combine with the Form Fly but that $1 t$ does with the Form Walk, this means that the Form Man and Form Walk are necessar1ly combined. The Form Man causes $11 k e n e s s e s$ of 1 tgelf and these 11 kenesses are capable 'of walking' by belng capable of belng caused also by the Form Walk. That this compatibility exists in the World of Forms, allows it to exist analogously so in the world of senses.

So getting back to this first version of the Third Man Argument, no harn can come to Plato's Theory of 
Forms. If you remore the anblgutty by saying "a man is ralking, but I know not which" this "third man' is simply some unspecified particuiar. It 18 your fault for not knowing who he 1s--not Plato's. If, however, you take the argument w1th the amblguous "man walks" the "third man' is nothing at all. Elther "man walks" is showlng the communion of Forms or analozously the participation of particulars (please note from the prior discussion of the above that participation in the Form World works both ways between Forms and hence is called 'combining', 'participation' in the world of sense 18 a one-way relation--the Forms cause us, we do not cause them, or we are resemblances of the Forms, they do not resemble us). The "man' in "man walks" is not some third intruder, nothing comes in between the Forms and particular nor over and above the Form.

Another Third Man

This Third Man 18 attributed to the Megarian contemporary of Plato, Polyzenus, by Phanias in a letter to Dlodorus.. Alexander quotes from that correspondence Polyxenus' argument,

If man 13 man in virtue of partaking and particlpation in the Form or autodvipwtos, there must be a man who has his belng relatively to the Form. But neither the autuávopwros sho is the Form, nor the particular man, is in Virtue of particlpation in the Form. The remalring possibllity is that there shouli be a 
third man who has being relative to the Form, 20

Polyxenus' Third Man is quite similar to the previous Third Man in that there is found a need (supposedig) for a third man apart from Form and particular. It is 8imilar too in that it stresses the difference between the Form Man and the particular man and in doing so leads the way to a 'third man' without an infinite regress. But instead of using a common statement such as "man walks" for 1ts bas18, the second Third Man hinges upon several ambiguities--or so it seems the word 'man' and Socrates' trouble w1th 'v1s1bles.' Cherniss writes:

The Platonlsts say that 'man' ( 8 \&v $\vartheta \omega \omega \pi \circ c)$ exists by participation in the 1dea. Then what is \& \& \& vpwros whioh has its existence in relation to the 1 deas it cannot be altoávipwros, for that is the 1dea, nor can it be the partloular man, for they do not say \& iis av vowros but 8 av 9 pwros. Therefore the subject of this Platonlc dictum must be a 'third man.' The use of the unirersal subject 'man' Instead of 'each and every particular man' gave Polyxenus the opportunity to argue that the statement of the platonists implied a 'third man' apart from the particular and the 1dea although they admitted the existence of these two alone.21

So 1t seems that an ambiguity rests again with

'man' and the desire to posit some 'relation' between Form and particular, at least as Alezander has recorded. That we know of the argument third-hand (not som Polyxenus, not from Phanlas, but from Alexander) may 
present even more difflculties. John Burnet, for example, contends that polyxenus (in the above argument) uses two terms for 'participation' ( $\mu \varepsilon \tau 0 \dot{x} \dot{\eta}, \mu \varepsilon \tau o v \sigma i \alpha$ ). which Plato never uses which leads him to belleve that Polyxenus never intended his argument against plato (or Socrates). 22 Taylor, taking the cart before the horse for a change, does not give much weight to Burnet's conclusion for who else can the argument be against? The Pythagorean Timaeus 1s, according to Taylor, the only other 'frlend of the Forms' who held that part1culars exist by virtue of 'participating' in the Forms and that TImaeus "avolds the use of the words $\mu \varepsilon \tau \varepsilon \dot{\varepsilon} \chi\llcorner\nu$ and $\mu \varepsilon \dot{\varepsilon} \vartheta \xi \iota \varsigma$ in a very remarkable manner ..." 23 There does, of course, remain the possiblilty that Polyxenus' words did undergo some modification in the hand-downs, if so, Burnet's conclusion is indeed shaky. Taylor reminds us that one's preference for words (Polyxenus' preference for $\mu \varepsilon \tau o x \dot{\eta}$ over $\mu \varepsilon \tau \varepsilon \dot{\varepsilon} \chi \varepsilon \downarrow \downarrow$ need not change things too much, if any. 24

Clemens Breumker. finding the ambiguous 'man' of the Platon1sts too ambiguous, decided to clarify matters by interpreting 'man' in the first Iine of Polyxenus' argument as a particular man, "der sinnfallige Mensch", 25 further, he makes this transposition:

Th1s cannot be the autoávipwios, who 1s 
the Form, nor get the particular man who is

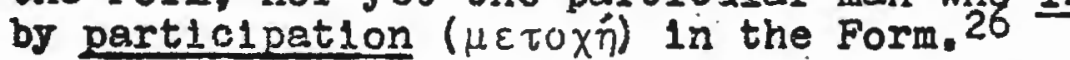

Whereas, however, as shown on page twelve of this thesist nelther the Form nor the particular, is in virtue of particlpation in the Form. Baeumker seems to remore the third man by making it a particular man who is by particlpation. And, as Cherniss points out, if there is no 'third man' in the argument, why should it be called a Third Man Argument? Why should it be almed against the Theory of Forms? ${ }^{27}$ Bf st11l other commentators, Baeumker's interpretation is met with mized emotion. Taglor reluctantly held to Baeumker's words at first, attempting to see an 'Intermediate man' much In the sense that F1ato has 'mathenaticals' as intermediates between the Forms and particulars in Mathematics, bat then he returned to Alexander's rendering. ${ }^{28}$ Burnet clalms that he is following Baeumker's transposition; however, the conclusion he draws shops just the contrary. Burnet clalms that particulars stand in no relation to the Forms--that only some perfect instance could and that this would be the 'third man.29--but Baeumiker's transposition already suggests that particulars do stand in relation to the Forms $\nabla 18$ participation. And Cherniss, as impiled abovs, would I1ke to toss Baeumker clean away. 
Robert G. Turmbull, who 1s currently working on his own translation and commentary of the Parmenides, writes that Polyxenus' version of the argument is Implied in the Parmenides at 130A-130E. 30 Turnbull seems to read the argument much the same way that Alexander does and attempts to show that there st11l remains a 'th1rd man', a sort of odd 'third man' that appears as a share in a particular man, but of no real threat to Plato's thoory. What Tumbull finds important is that this argument does allow a 'third man,' although if something like 'Ilkeness,' 'Beauty, ' or 'Justice' vere to replace 'Man.' the argument would not be so forceful, he goes as far as to say that the argument would not even be valid against these. In other words, this argument seems to be a limited attack upon the Forms-or at least against a ilmited number of them (Forms of visibles). 31 At Parmentdes 130A Parmenides asks whether as there is Likeness apart and distinct from the l1keness we have, if there is also Man, apart and distinct from us. Socrates replies that he is not sure, he had loris had trouble with maiking a decision about 'v1sibles,' although things such as f1lth and mud could not be since they are not ospable of siriving to be better filth and mud. The transiation of parmenides 130A-13E as Turnbull gives it is as follows 
Parmenides socrates, your zest for argument is thoroughls admirable. Tell me, is this jour invention, this distinction separating, on the one side, the forms themselves, on the other, those which partake of them? And do you think that there is Likeness itself, separate from the likeness we have, and one and Many and all the rest of which jou just now heard Zeno speak?

Socrates Certainly.

Parmenides Are there also these, a form just by Itself for just, another for beautiful. another for good, and others for all such things?

Socrates Yes.

Parmenides And what of this? Is there a form for man, separate from ourselves and all like us-a form by itself for man, arother for fire, another for water?

Socrates I have many times, Parmenides, been In straits concerning these, troubled whether one must speak this way or otherwise concerning them.

Parmenides And what about these, which may seem to be absurdities, halr, mud, dirt, and other quite undignified and trifling things? Are jou in straits whether one must say that there is a separate form for each of these also, a form which is other than the things which we hold in our hands?

Socrates Not at all. These are s1mply what we see them to be. It would be too disgusting to believe that there is a form for these. Even so, I have sometimes been distressed at the thought that what holds for one thing does not hold for a.1. But then, when I take this stance, I flee, lest I perish in an abyss of babbling. So, when I come back to those things which we just now sald do have forms. I work away at varlous matters concerning them.

Parmen1des You're st1Il young, and phllosophy has not yet gripped you as firmiy as I think it will later. Then you 1111 be disgusted at none of these things. Right now, in your youth, ygl are over attentive to other people's oplnions. 32

Socrates had earlier brought out the point that Forms must be separate from particulars to account for an 


\section{8}

1ndividual belng both '11ke" and 'unl1ke.' That 1s, a man can be said to bo both short and tall without belng contradictory as long as short and tall are not actually the same as the individual. He can partake of 'Shortness' when someone $1 \mathrm{~s}$ taller than he and he can partake of 'Tallness' when someone 18 shorter than he. He can be both short and tall in relation to these other individuals. Although perhaps a clever answer. Parmenides wants Socretes to make it completely clear and 1 t 13 implied that there oould be a problem (at least w1th 'v18ibles'). Turnbull states the implied argument.

If a given individual is $f$, then, to aroid the difficulties of the zeno argument, we must think that the ind17idual partakes of a form $F$ and that the form itself $1 \mathrm{~s}$ simply in the sense of being self-identical. To partake of $\underline{F}$ 1s, by the very meaning of the word. to have a share of F. Thus we must distinguish between the 1ndividual, the $f \mathrm{rm}_{\mathrm{m}}$, and the share the Individual has of that form. 33

Although this mas be a difriculty with 'man,' Turnbull

points out the difference w1th 'I1keness' w1th the

following example:

If Jones (a man) partakes of I1keness, he has or comes to have a (second) I1ke in him. But for Man (or Horse, ete.) the situation is quite different. If Jones (f1rst man) partakes of or comes to partake of $\operatorname{Man}$ (second man), he has or comes to have a (third) man in him. But Jones alreaiy is a man! The contrast, in Parmenides' questions, between 'separate from the l1keness we have' and 'separate from ourselves and all

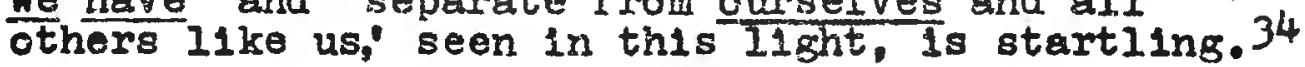


of course, the Third Mars Aroument (Polyrenus' rersion) is only ImpIled here because Socrates did not really answer that there was a Form Man. Accorting to Turnbull, then, If 'Tlsqbles' are taken as Forms, jou will have the queerness of actuaily having another man in you so that you might be colled a man, whom yon already in fact are. Tumbull suggests, "Socrates ought to be 'in stra1ts" about this matter!" 35 . But this 1ntermediate 'third man, : coming about as a share apart from the Form, again, 11ke the flrst 'third man, does not deny the uniqueness of Plato's Forms, but this time only that something rather strange occurs when 'visibles' have corresponding Forms and are treated in the same way "immanent characters" are, that 1s, by having a share in this case.

I think, however, that there could be a way out for this 'queerness', possibly by defining 'particlpation' In a way other than sharing, as Socrates does go on to attempt (and later Rarmenides himself) and further by treating 'vigibles' unlike 'Immanent characters.' Taking once again AIIen's notion of: Forms as exemplary causes, If the Form Man: (Man. I) causes: Jones: to be relatively man (Man II), then why should Jones come to have an additionel mafi in h1m? That 1s, Jones is: not even a first man until he pertakes of the Form Man.. And since-it is the second 
nor 18 there any need to sneak in another man. The difference between 'Immanant characters' (such as the beauty, Justice, 11keness, etc.. that we have) and 'visibles' (me, you, the feliow next door, the nelghbor's dog, etc.) should be shown in this way the 11keness we have is so in virtue of Likeness-1tself; the man that I an 1 s so in virtue of Man-itself. I do not already as a man come to partake of Man and have another man put in me; I can, however, already as man, come to partake of (to a greater axtent) Taliness (I no doubt already hare some share unless I am the smallest possible thing), retire to my stretcher and emerge with a larger share of tallness in me. So 1t seems that Plato could have Forms of 'visibles' without ruming into this particular 'third man' as an intermediato share within a particular.

This route could possibly pose a problem but only if combination of Forms were impossible. Plato speaks of Forms as standards which all else should be striving for (Phaedo 75A). One can strive to be Just, or to be Beautiful--but if one is already a man, how can he strive to be Mani He would have to strive to be a better man-that 1s, to be Just, Brautiful, and the 11ke. This would suggest a kind of 'communion of Forms,' another sense of 'part1cipating' which I belleve plato relntro- 
duces in the second part of the Parmenides and elaborates more fully upon later in the Sopks later in conneotion with the main version of the Tinird Man Argument get to be considered.

For now, th1s second Th1rd Man, 11ke the prevlous, does not, I think, pose any special problem to Plato's Theory of Forms. ${ }^{36}$ At best 1t comes in as the queerness of having a man in you, but with R. E. Allen's insight Into Plato's ontology (Forms as exemplary causes and particulars being relational entitles), plato (so far) has no 'third man' to worry about--and as shown in the Republic (597C) and the Timaeus (48E-51B), w1th Forms of all visibles in the latterl, he didn't.

\section{A Third Third Man}

The th1ra Third Man part I (found at the beginning of Alexander's discussion) is generalls accredited to Eudemus and Its implications lead one to the infinite regress found in part II, Alexander ascribing that part to Aristotle. It is this Third Man which brings the most controversy-that 1t seems to be val1d and that Plato poses it himself In the Parmen1des (although exactly how it is ralid, what It is valid ageinst, where it is found, or if there is an escape from it 18 debatable). First it would be in order to give Alexainder's rendering; 
Part I.

The argument which brings in the 'third man' Is as follows. They say that the substances which are predicated generally are the true and proper substances, and that these are the Forms. Further, things which are 11ke one another are so in virtue of particlpation in one and the same something which properly is that, and this 18 the Form. But if this is so, and if that which is predicated in like manner of several things, when not identical with any one of those things, is another thing over and above them--and $1 t$ is just because the Form of Man, though predicated of particular men, is not identical with any of them that it 13 a kind--there must be a third man besides man particular-as; e.s. Socrates or Plato--and the Form, which last is also itself numerically one. 37

Part II.

If what is truly predicated of a plurality of subjects is a reality alongsile those of which it is predicated and distinct from them--and those who postulate the Forms belleve they can prove th1s.:. If so, I say there w1Il be a 'third man.' For if Man as predicate is other than the men of whom the term is predicated, and has a substantial being of 1 ts own, and $1 f$ man is predicated in like manner, both of particular men and of the Form, then there must be a third man distinct both from the particular men and from the Form. And in the same way a fourth, predicable in $11 \mathrm{ke}$ manner of this third man, of the Form and of particular man, and again a fifth, and so on in indefinitum. 38

Thus, the f1rst part of the arsument is basically

this, if we grant that substances are the Forms and that these are predicated of particular things in this world, and further that all these particular things are like one another in virtue of their particlpation in the Forms (the particulars imltating the one over the many), 


\section{2i]}

then to give the unfty which was perkaps the purpose of the Platonic doctrine; one must soinehow unite the Form, say of Man, and the particular man with some 'th1rd man.'

Plato's theory of Forms, had, of course, come at a time of philosophical chaos. The Sophists at the end of the fifth century B.C. had brought harm as well as good to the people of Greece. No doubt the Sophists taught many useful things, but too often they played with words making things seem as they were not or rraking them seem as they would like them to be. Absolute truth and standards lost their relgn to a sort of relat1vism where 'opinton' ruled and almost any opinion could rule because language 1tself was amblguous enough to allow for 'proofs' (the Thtrd Man Argument stands as an example) of practically anything. "Might makes right," OpInion is truth," and the world $1 \mathrm{~s}$ mede up of many constantly changing things. Greece was in a turmoll ethically, epistemologically and ontologically. Plato sought to restore unity and the doctrine of absolute unchanging Forms seemed the answer. The attempt was an economical one, as Cherniss says:

The dialogues of Plato, I belleve, will furnish evidence to show that he considered it necessary to find a single hypothesis which rould at once solve the problems of these several spheres and also create a 
rationally unifled cosmos by establishing the connection among the separate phases of experience. 39

Cherniss goes on to show that aithough Plato's first Interest was Ethics, Eplstemology and eventually ontology entered in to give the complete ploture. Joseph Moreau also sees the Platonlc doctrine arlsing in the form of explanatory roles finding the same basic functions as did Cherniss: 'gnoselogical,' serving as the foundation for knowledge; 'axlological,' serving as a foundation for values and ethics; and 'cosmological.' serving as the foundation for the existence of the universe. 40 The first part of this third Th1rd Man, bringing in jet another rotion of unity. finds some 'third man' necessary to unite what appears to be two separate existenees: Forms and particulars. The troublo is, desplte appearances, the creator of this argument is so bound in the worla of flux, so set, no doubt, on the notion that he himself $1 \mathrm{~s}$ the stable entity, that knoingly or not, he is taking particulars as substances (as well as Forms) which Plato would never think of dolng. Golng bacis to Allen's distinction yet again, particulars are relational entities and not substances. Forms and particulars are in no need of some further relation to unite them. The Forms and their dependents already constitute a unity-a sort of 'organism' as W1ll1am F. Lynch ${ }^{41}$ would have it. 
But more of th1s later. Let 1 t suffice for now to say $1 f$ knowingly or unknowingly one elso takes particulars as substances (as well as Forms), then one has the existence of tro separate substances--and then it 18 natural to suppose that some sort of 'relation' should exist between the two, jlelding, if you wish, a 'third $\operatorname{man} .42$

The second part of the argument, as Alexander states 1t. supposes that if the Form Man is something other than the particular men $1 \mathrm{t}$ is predicated of, and that both of these are Man--that 1s, that Man can be predicated of both the Form and partloular (they are both called 'man'), then this last 'man' would appear as a 'third man' standing distinct from and over the Form Man and the particular man. This 'third man' would then have the status of the 'one orer many' and hence appear to be a Form, Form Man II. And then, of course, it might be asked if this new Form can be sald to be somehow 11 ke the Form Man I and the particular man and the same in reverse. The answer seems to be , surely, they are all called man. So this new 'man' becomes a fourth in the echeme of things (Form Man III), if one presses this matter further, a fifth, sixth, a seventh, an infinite number of men will appear, each standing as a new Form (another duplicate) over the group of other duplicate 
Forms, the original Form and 1ts particulars.

Th1s is the argument that Alexander attributes to Arlstotle, orginally rocorded in Arlstotle's Concernins Forms (now lost) and no doubt this is the variation of the argument Arlstotie uses since he elaborates on 1 t further in h1s Soph1stical Refutations at 178b35-179. I give here Turnbull's translation of that passages

(There 1s) also (the argument) that there is a third man besides the same (1.e., man) and those with regard to each (individuals). For nelther 'man' nor any common term signifles a tode t1, but rather a quality, a relation, a mode, or some such. Likewise 'Cor1scus' and (Corlscus' Musician'. CAre they the same or different? For the one signifies a tode ti. the other a quality, so that the same (1.e... musician) is not set apart. It is not the setting apart which makes the third man, but rather the uniting 1nto tode t1. For there will not be a toce t1 encompassing both Callias and the one who is rar. Nor vill it make any difference if one were to say that the setapart is not a tode $t 1$ but rather a quality. For there will stili be a one besides the many, for example, man. It is therefore clear that one muet not grant that something predicated--in common--of all is a tode $t 1$. but rather that it signifies quality, relation, a quantity, or some such. 43

Now, Arlstotle is correct, I think, in saying that this 'third man' comes about by connecting the Form and the particuiar, he is correct too in saying that it is a mistake to set apart a 'second' man in the first place-but--for the exact oppesite reason he gives. The mistake, he thinks, is to set apart the Form as a this (tode t1) -- a 'th1s' for Ar'stotlo meaning 'substance.' 
He 18, I think, flatly wrong, falling into the same situation that we found Eudemus in the flrst part of the argument as Alexander records it. True, it is a mistake to set something apart, but that 'something' is not the Form, but rather the part1cular. It 18 when one treats particulars as substances that the 'third man' (and in this case infinitely others) appears. It $1 \mathrm{~s}$ when one belleves that 'man' is a predicate and that it can be predicated of both Form and particular that the 'third man' appears. It is when particulars are 11terally separated from the Forms that the "third man' appears. We must remember, and remember always, that plato has truned what we commonly perceive as reality inside out. This is a relational sort of existence that we have, true exlstence is in the realm of the Forns. These Forms are not mere abstrections standing as qualities or attributes to substance; they are substantlal and the higher the Form the richer it is. As Comford says:

Suppose that Form (Being) to stand at the head of the whole hierarachy. If 1 t were the barest of all abstractions, nothing colzid be got out of 1t by an attempt to divide it into parts. It would have no parts, but be $81 \mathrm{mple}$ and Indivisible as the one Being of Parmenides. In Plato's view the highest Form, whether it be called 'Belng' or 'the One' or 'the Good'. must not be the poorest, but the richest, a universe of real belng, a whole contalning all that is real in a single order, a cne being that is also many. Such a Foril is as far as 
possible from resembling an Arlstotelian category, for the categories are precisely the barest of abstraction, at the furthest remove from substantial reality. 44

It seems that Aristotle did not learn his lesson too well, if he did, in fact, hare access to Plato's Parmenides (as he likely did) or else he would never have presented the Third Man Argument as a valid objection to Plato's Theory of Forms. He, l1ke most of us, 18 too much caught up in the world of appearance. But this argument does show quite well our predicament in this existence, we are faced with problems of predication, participation, 1mitation, degrees of reality, unity, and our thinking can even lead to infinite regress. This Third Man Argument, unlike the other two, stresses not only the difference some construe between Forms and particulars, but also the likeness, and Forms giving up their unlqueness give rise to infinite duplications. since this is the first Third Mar to bring forth a regress, perhaps we should pause for a moment to discuss 'regress' itself along with some other 'instances' of 1 t.

Regress Itself

Regressus in infinitum has been a frustrating ploy for quite $a$ wile and $1 t$ does not show any signs of letting up. Zeno of Elea's line of dichotomy, depressed fleet-footed Achilles a loser to a turtie, arrow (alas) 
without any movement, and charlots passing in half of length of time the whole length of time--plus some 'third man' does not add up to the whole of infinity. Jorge Luis Borges 45 adds to the 11 st Comel1 us. Agrippa, the skeptic who conjectured that every proof stands In need of a previous proof; hence we sannot be certain of anything (Hypotyposes, I, 166), And also to the list goes Sextus Empiricus who has no faith in definitions since each of the words within the definition needs also to be defined, and then, or course, those: words need defining and so on forever (Hypotyposes, II, 207). Perhaps less well known is Chuang Tzu, who according to Borges, uses infinity to dispel the 1dea held by some Chinese monists that the Un1verse was a single thing eren though it consisted of Ten Thousand Things. Immediately there is more than one "because cosmic unity and the declaration of thet unity are already two things: those two and the declaration of their duality are already three; those three and the declaration of their trinity are already four." (Waley, Three Ways of Thought in Ancient China, p. 25). This example is not too far removed from Plato's own discussion of Unity in the second part of the Parmenides, 46 there, Parmenides, in h1s dialectical exercise intended for younger members of the Academy, says that Unlty cannot be one because already. there is the Belng that it has, then the Difference 
between that Being and Unity, and then the differences between the three and so on (the usefliness of this particular argument, as I see 1t, will be shown in Chapter III). Finally, concerning regress, Borges asks, "Is it a legitimate instrument of inquiry or merely a bad hab1t? 47

Bertrand Russell tends to bring an answer; he distingulshes between a harmless regress and a logically viclous type. The former is constituted only by 1mplications between propositions. There is no real objection to say that 'proposition I' leads to 'proposition.' which leads in turn to 'proposition $3,^{\circ}$ and so on into Infinity; 'proposition $l^{\prime}$ ' can have some positive true meaning--and that true propositions follow from it 18 Indeed harmless. 48 Taylor insists that the 'formal Implication of the Idealists involves this kind of regress (which might more adequately be called a progress):

In fact, on the hypothesis of 'Ideal1sts' of the kind who usually make the most frequent employment of the 'regress' against their opponents, every true proposition ' $p$ ' must imply an infinite series of true propositions. For they commonly hold that a proposition cannot be true without belng actually known by some mind and that this 13 part of what we mean by calling ' $p$ ' ture. Hence the true proposition, ' $I$ lmows $p$ ', and this, being itself a true proposition, again implies 'y--who may of course be 1dentical with $x-$ knows that $x$ knows $p$ ' and so on in indefinitum. 49

The second type of regress that Russell Fefers to 
is the viclous one. This regress mekes even the first proposition meaningless--since the regress comes out of an attempt to determine 1 ts meaning. Russell chooses even not to call such an utterance a proposition since propositions much have some determinate meaning. If to arrive at the meaning of a 'proposition' we must first pass through an infinite number of others, we shall never arrive at that proposition. 50

The question which comes to the subject of this thesis, 18, of course, whether the regress found in the th1rd Third Man Argument is such that 1t shows that propositions involving the Platonic Forms, particulars, and their 'relationship' (as posed in the first part of the Parmenides) to be somehow lacking in meaning. If one assumes that the symmetrical (two-way) relation of particulars to Forms and of Forms to particulars is what Plato actually held, the argument, although vicious, 1s userul in that it clears the alr for other theorles-as Aristotle no doubt thought it ald for his own. or some might think that the argument was such a blow to Plato that he revised his ow theory. If, howerer, one shows that Plato never intended a symetrical 'relationship' (or any sort of relationship between Forms and particulars) 51 then one might say that he was actually 'clearing the a1r' for his own theory-trying to eliminate or at least at present trying to expose foolish notions 
rooted in the ambigultied of language. The latter is what tinis thesis intends to give some evidence for, as will be seen in the following chapters. 
Notes

II am vell aware that this is not Zeno's Stadium Paradox (named so because of objects traveling the whole time in half the time in a stadium), however, anything worthwhile (such as the performance of some 'third man') should take place in a stadium for all phllosophers to enjoy. Apparent ly 1 t was actually the case in early Greece that dramatists and dialogue-writers were given audiences at the olympic Games. See Gllbert Ryle, Plato's Progress (Cambridge, Cambridge University Press, 1966). pp. 33-35.

2Unless specifled otherwise I will be using the translations of Plato's dialogues found in The Collected Dlalogues of Plato, ed. by Edith Hamilton and Huntington Calms (New York: Pantheon Books, 1964).

3r1maeus 48E, $50 \mathrm{C}$.

4 am using 'Man' here as an example although Plato sometimes seems to have doubts that there could even be such a Form. Socrates at Parmenides $130 \mathrm{c}$ expresses his doubt that there are Forms for man and the Iike, however, I doubt that Socrates is really the mouthpiece of Plato as I vill show later. Further, there does seem to be evidence to indicate Plato's willingness to include Forms for every sort of thing (Pepublic 597C, Cratylus 389B, Timaeus 51B-52C, seventh Letter 342D; and the Academy, after all, does call the argument the Third Man.

Sphaedo 100C-101C

6 Th1s w11l be demonstrated in Chapter III.

7Republic 597C, Parmen1des 132A, Timaeus 31A.

BI w1ll be using A. E. Taylor's translation of the arguments recorded by Alexander. A. E. Taylor, Parmenides, Zeno, and Socrates, in Philosophical Studies (F'reeport, New Yorki Books for Libraries Press, 1968), pp. 54-59.

Traylor, parmentdes, Zeno, and Socrates, py. 55-56.

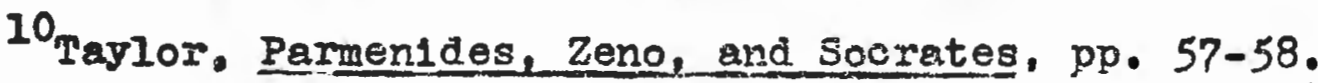

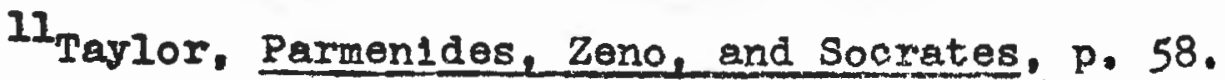


12 Harold Cherniss, Ar1stotle's Critioism of Plato and the Academy (New York: Russell and Russell, 1962), pp. 501-502.

13R. E. Allen's term. See "Participation and Predication in Plato'3 Middle Dialogues," In Studies in Plato's Metaphysics, ed. by R. E. Allen (New Yorki The Humanities Press, 1965l.

14 Allen, "Participation and Predication," p. 46.

15Allen, "Participation and Predication," p. 58.

${ }^{16}$ Cratylus $411 B, C$, and $439 C$.

17 Alien, "Participation and Fredication," p. 58.

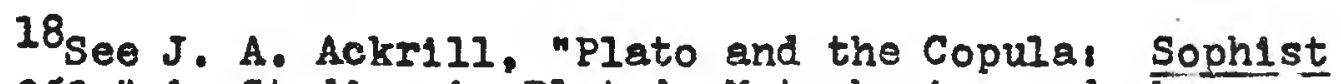
251-259," in Studies in Plato's Metaphys1cs, ed. by B. E. Allen (New York, The Humantties Press, 1965), p. 213.

19 Professor Donald Zeyl of the University of Rhode Island presents this view:".. I am inclined to think that 'man walks' could be read simply as a statement about the Form 'Man', not in the sense that Man qua Form walks--since Forms are 1mmobile-mbut that Man qua being the Form that 1t is, viz. the Form of Man walks. To put this in a later terminologs! it is part of the immutable nature (essence) of Man that he walks. In this sense 'walking' might enter the definition of the Form 'Man." That 1s, men are capable of walking.

20 Taylor, Parmenides, Zeno, and Socrates, p. 63.

21Cherniss, Aristotle's Criticism os Plato, p. 502 .

22 John Burnet, Groek Philosophy Thales to Plato (London, Macmillan, 1955), p. 259.

23 Taylor, Parmentdes, Zeno, and Socrates, pp. 60-61. 24 Taylor, Parmenides, Zeno, end Socrates, p. 62.

${ }^{25}$ Clemens Baeumker. Rheiniches Museum, XxxIV, pp. 84, 18. See Cherniss, Aristotlels Criticism of Plato, p. 503. ${ }^{26}$ Baeumker, Rheiniches Museum, pp, 84, 20. See Cherniss, Aristotie sCriticism of pleto, p. 503, and 
Tajlor, Parmenides, Zero, ard Soczates, p. 65. 502.

27Cherniss, Aristotle's Criticism of plato. pp. 501-

28 Taylor, Parmenides, Zeno, and Socrates, pp. 58059 , $62-63$.

29 Burnet, Greek Ph1losophy, pp. 259-260.

30 Robert G. Tumbull, "Plato's Repudiation of the 'Separation of the Forms in Parmenides 127B-1350." unpubl1shed, pp. 19-20.

31 Turnbull, "Plato's Repudiation," p. 20.

32 Turnbull, "Plato's Repudiation," pp. 14-15.

33 Turnbull, "Plato's Repudiation," p. 19.

34 Turnbull, "Plato's Repudiation," pp. 19-20.

35. Turnbull, "Plato's Repudiation," p. 18.

${ }^{36}$ professor zeyl, taking the literal reading of the argument (contra-Baeumier), contends:

The appropriate response to this sophlstic objection would be to say that when the Platonists say "man exists by $\nabla 1$ rtue of a relation to an Idea they mean by 'man' the whole disjunctive set of Individual men, each of which exists in that maxner. In this way the solution to this second puzzle reduces to one of the possible alternative of getting out of the first.

37 Taylor, Parmenides, Zeno, and Socrates, pp. 54-55. 38 Taylor, Parmenides, Zeno, and Socrates, p. 56.

39Harold Cherniss, "The Ph1losophical Economy of the Theory of Ideas," in Flato I. Metaphysics and Ep1stemology, ed. by Gregory Vlastos, Anchor Books (Garden C1ty, New Yorki Doubleday and Company. Inc., 1971), pp, 16-17.

40 Joseph Koreau, "The Platonic Idea and 1 ts Threefold Function: A Syidthesis," International Phllosophlcal Quarterly. IX (December, 1969), 477-517.

41 H1111am F. Lynch, An Approach to the Metaphysics of Plato Through the 'Parmenides TWashington: George- 
town University Press, 1959).

42 Professor Zeyl offers a constrasting translation and commentary of the first part of the third Third Man as presented on page 22 of this thesis. Belng uncertain of translations of Greek at this time, I think it only fair (especially if Taylor is indeed incorrect) to present Professor Zeyl's interpretation. His transiation of that first part of the third Third Man is as follows:

The argument which introduces the Third Man is of the following sort: they say that the things which are predicated in common of substances are such things in a full sense, and these are the Ideas. Further, things which are I1ke one another ere like one another by sharing the being (metousia) of some one thing. which is that in a full sense; and this is the Idea. But if this is so, and what is predicated of some things in common, without being 1dentical with any of those things of which it is predicated, is something else besides them, there will be a Third Man besides the particular one such as Socrates or Plato, and besides the Idea, which itself also is one in number.

Professor Zeyl's interpretation is this:

(1) The things which are predicated in common of (a set of) substances are those very things in a full sense. Thus man. which is predicated of $S$, and $P$. is Itseli \& man, and ran in the full sense. (And from that S. and $P$. are each like what is predicated of them. This is necessary for the third step.)

(2) Whatever things are 11ke one another share in something else which 1s fully what they are: thus if $S$. is ilke $P$. they share in something which is fully F (e.g. man).

(3) But 'man' is predicated in common of some things (as $S$. and $P$. and--here is the relevant case--as $S$. and his Form; this by (1). This 'man' cannot be 1dentical with what it is predicated of (and thus it must be non-identical with both $S$. and the Form).

(4) And so it is that we have the 'Third Man'. besides $S$. and his Form.

43 Turnbul1, "Plato's Repudiation," pp. 29-30.

${ }^{44}$ Franc is Cornford, Plato's Theory of Knowledge The Library of Liberal Arts (New York: The Bobbs-Merrill 
Company, Inc.. 1957), p. 270.

45 Jorge Luis Borges, Atartars of the Tortolse in Other Inquialtions 1937-1952 (New Yorks Washington Square Press, 1966), pp. 114-120, passim.

46 parmenides $143 \mathrm{~A}-\mathrm{D}$.

47Borges, Avartars of the Tortolse, p. 119.

48 Bertrand Russell, Princloles of Mathemat1cs The Norton Library (New Yorki W. W. Norton and Company, Inc., n.d.). p. 349 .

49raylor, Parmen1des, Zeno, and Socrates, pp. 47-48.

50Russell, Principles of Mathematics, p. 348.

51W. F. R. Hardie, A Study in Plato (oxford: The Clarendon Press, 1936), pp. 96-97. 
II

THE THIRD MAN IN THE PARMENIDES

\section{The 'Parmenides' Itself}

Although one cannot be certain of precise dates, there tends to be general agreement that the parmenides stands as one of Plato's 'middle dialogues'--coming after the Meno. Phaedo, Symposium, Republic, Phaedrus, and coming before the Theaetetus, Sophist, Statesmar, Philebus, and Eaws. I (Two of Plato's dialogues, the Cratylus and the Timaeus, for various reasons, ${ }^{2}$ seem not so stable in the accepted chronology of Plato's works. My interpretation of the parmenides leads me to believe that both come after that dialogue but it is of no great significance to my thesis where they comem-that Plato wrote them at all is the important thing.) The Parmenides itself has met with many reactions; 1ts role in Plato's development has been greatly debated. It has been thought to be a turning point in Plato's Theory of Forms ${ }^{3}--h i s$ theory undergolng considerable change after the problems presented in that dialogue. It has also been thought to be of little signiflcance philosophically: the arguments in the flrst part (including the Third Nan) being mere sophisms or that they are invalid and Plato know they 
were; in the second part of the dialogue Plato turns the tables and meets the scphisis using sophisms against what they hold true, a joke, 4 There are, howerer, some commentators who find the dialogue not only serlous, but also having positive philosophical 1mport. Gilbert Ryle (In 1939) thought that the whole dialogue could be seen as an introduction to the theory of types--the first part of the dialogue presenting arguments to demonstrate that It is 1llegitimate to speak of Forms as having any sort of 'relation' to perticulars, and the second part presenting arguments to show that some Forms must be treated In a unique way. 5 closer yet, I think, to finding the unity of the Parmenides is W1lliam F. Lynch, he finds that the 'one-many' problem persists throughout--the second part of the dialogue attempting to answer the first. 6 But, the first to argue for the unity of the dialogue, Gilbert Byle, now thinks the parmenides is 2 piecemeel of two works hast1ly joined together for the purpose of not getting lost.? It might be well to conElder the division.

The Division

According to Gilbert Ryle in Plato's Progress the first part of the Parmenlies was being written during Plato's switch over from eristlc alalogues (in which Plato 
mostig recounts dialogues actually heard) to his dialect1c (In which the dialogue become 11ttle more than a 'yes,' 'no.' or 'so 1t seems' alongside full blown arguments). Ryle thinks that Plato might hare originally intended to deliver 1t at the olymplc games, but that it $1 \mathrm{~s}$ more $11 \mathrm{kely}$ that it was the sort of thing he might prefer to give to his followers at the Academy. 8 In two previous dialogues, the Crito and the Phaedo, Plato had basically renumerated earlier arguments from previous dialogues (Gorg1as, Meno, and Alc1blades I) which seems to indicate that Plato was running out of material--and hence ended his public performances. 9 Ryle says:

- his concern for the tastes of the lalty
was now belng displaced by concern for the
Judgements of the members of the Academy. He
was ceasing to work for success as a composer
of disputation mines and correspondingly the
Athenlan citizens. yere ceasing to care for
his compositions.

Now, as business-11ke as the f1rst part of the parmenides 18, the second part is undoubtedly for the more serlous ph1losopher wishing rigorous training in dialectic (as: 1t is Implied at Parmenides 136E). Ryle supposes that there were no students ripe for this sort of reasoning at the time when the first part of the dialogue was written which might suggest that the secord part was indeed written later. ${ }^{11}$ It might also explein why the dialogue changes from orat10 obliqua (at 137C) to oratio recta 
(w1th only one "he sald"). G. E. L. Owen in his "Notes on Ryle's Plato" 1s quick to point out, howerer, thisi Plato doesn't even keep up the "Antiphon told me that Pythodorus told him that Socrates said.. " In the first part, further, that Plato has been known to shift the sense in the Republ1c as well (134B-D). 12 But in any case, whether or not some time elapsed between the writing of the first and second parts (to allow for students to mature). I do not agree with Ryle that the two are not complementary, nor that Plato's motive in jolning the two was simply to tack them together lest they be lost. That the two parts are toploally compat1ble w1ll next be consldered.

The Unity of the Parmenides

There are several reasons, I think, to assume unity in the Parmenides. To begin with, Parmenides is the leader of the dialogue throughout (desplte the fact that It is not related third-hand in the second part), and in each 'part' of the dialogue alongside Parmenides one finds a young, inexperienced student of phllosophy (first Socrates, later Aristoteles). Further st1ll the 'onemany' problem is confronted five times in the dialogue: twice in the first part ('particular to attributes,' 'Form to particulars') and three times in the second part (The one to Forms,' 'Form to particulars,' 'part1cular to 
attributes'). This latter consideration w1ll become more clear in a summary of the Fermenides yet to come, and hoperully substantially clearer in Chapter III where the second part of the Parmenides is suggested as an escape from the 'third man.' The former will be discussed Immediately.

Historically, most commentators agree, this dialogue (the Parmen1des) could not have taken place. ${ }^{13}$ This would meet with Ryle's vlew that Plato is venturing off on his own, leaving behind actual recordings of Academic Moots. 14 Why, one might ask, is Parmenldes given the lead role? Cornford suggests that Plato was quite impressed with Parmenides and that he ". . looked upon himself as the successor of the man who had flrst drawn, however 1mperfectly, the distinction between the intelliglble word of truth and reality and sensible world of seeming and becoming."15 Another reason might be Plato's growing desire for rigorous dialectic as the historical Parmenides was known to have had. A. E. Taylor thinks that arguments such as the Third Man were just the sort of arsuments that the historical Zeno might have and in fact probably did ralse to "friends of Forms," Plato or otherws se (Pythagoreans)--and that these arguments were only sophisms. 16 maylor thinks that plato knew these were mere sophisms beling brought against his theory, so in part two of the 
Parmen1des he shows Parmenides hanging hinself with his ow logic. Taylor says, speaking for Plator "I can easily do with you as Zeno did with the critics of his Master Parmenldes--give you back as good as you bring and better, in way which will be highly diverting to a lover of dialectlc."17

The troubie is that the Parmenides presented in the dialogue is not particularly true to the historical Parmentdes and his 'One.' The dialogue does not argue agalnst the existence of multiple Forms, for these are assumed in the rirst part and, I think, proven in the second part. 18 The f1rst part is rather arguing agalnst particular literal interpretations of a relationship of particulars to the Forms. And at parmen1des 135B-C Parmenides does not conclude that there cannot be many Forms, but rather 1mplies that we must look for some other sense of 'partaking' to exh1b1t the 'one-many' (which, by the way, leads one to expect some attempt later in the dialogue since Forms are needed if we are to have knowledge). Parmenldes, h1stor1cally, d1d not doubt, perhaps, the existence of at least one Form ('One') and perhaps to throw doubt on Plato's multiple Forms might also succeed in making h1s own Form less secure. 19 So I think 1t is possible that the historical parmenides might give the sort of arguments appearing in the first 
half as well as the second, however, he would not be assuming many Forms as this Parmenides most certainly does. This leads me to conclude that 'Parmenides'

18 more Plato than Parmenides. Plato has been exhibiting h1s Form Theory in earlier dialogues--in the Phaedo most explic1 tly. Forms being diffoult to know and to speak of, the Phaedo is full of analogles. And perhaps, as is often the case with students, they take their professor's words too 11 terally and further impose their owm notions. (consciously not not), and it just might be that Plato, in the guise of Parmenides (in the first part of the dialogus) is showing his students, followers of Soorates like himself (represented by the young. inexperlenced Socrates), the ridiculous things that happen. when they do so. The 'third man' 18 one such result. And he,does this is such a cunning way as not to arrest their zest for knowledge. He does not want to belittle his students; he wants to guide them to h1s true doctrine. (If the foregoing 13 true, Aristotle apparently did not learn his lesson since he used the 'third man' as a val1d argument against Plato himseif.) But to understand his notion of 'partaking' one must understand the Forms and their interrelations. It is quite an exercise and not recommended for just anyone. Socrates is asked to observe a preliminary exercise in Parmenidean dialectic and the 
second part of the dialogue is such on exercise, and although it is difflcult, the 'one-many' and 'partaking of' are on the way to being expressable.

Summary of the Parmenides

A rather short summary of the dialogue might go I1ke this (the Th1 Id Man Argument will be considered in detall later--so too the 'second part' of the parmenides)' Zeno begins in the dialogue by playing with the one-many problem as it appears in particulars--hoping to show Socrates the contradictions involved in believing that reality is composed of many rather than Parmenides' 'One.' How can one particular both be like and unlike? (How can I be both short and tall, how can I be one when I have four $11 \mathrm{mbs}$ and an indifinite number of other things, often contrary within me?). The argument is not precisely given In the dialogue, but since its theme is important throughout and that one should know it in order that Socrates' reply be intelligible, I choose to gire Tumbull's interpretation of it (his being the clearest rendering I have found,

F1rst, suppose that $A$ is $\mathrm{A}$ and that $\mathrm{A}$ is $\mathrm{B}$. If A realiy is both $A$ and ${ }_{\text {B }}$ it is both one and the same as Tself and one and the same as $B$. Since it is one and the saice as itself and another, it is like 1tseif and that other. Since it is unqualifiedly the same, it is unqualifiedly $11 \mathrm{ke}$. : - But, to distinguish 'A is A' $\mathrm{from}$ 'A is $\underline{B}^{\prime}$. we must say that $\underline{A}$ is different from 
B. Given the meaning of "different from" (if jou please, "Is not"). we must say that it is unqualifiediy different from (no'tartic1pation':) and thus unqualiflediy unlike another. But the meanins of ' $1 \mathrm{~s}^{\prime}$ (1.e." 'Is one and the same as') in both 'A $18 \mathrm{~A}$ ' and 'A $1 \mathrm{~s} B$ ' must be the same, and the supposition requires that $A$ is B (or ${ }_{\text {. }}$. or whaterer). So if $\mathrm{A}$ is unqualifídedy different from B. It nust be unqualifiedly different from and thus unqualiflediy unlike itself. So, grating that an entity may be both itself and another (whioh is what the supposition. 'If many are'. amounts tol, it must be unqualifiedly $11 \mathrm{ke}$ and unlike both Itself and that other. The same reasoning, of course, applies to $A$ and $C$, and to $B$ and $C$. Indeed to any alleged paIrs of entities we may choose.

Second, and this step is comparatively simple, an entity which is unqualifiealy $11 \mathrm{ke} 1 \mathrm{tself}$ and another 1s, by definition, a 11ke, An entity which is unqualifiedy unlike itsolf and another is, by definition. an unlike. 20

To the above, which results in the notion that reality as many must be impossible, Socrates gives a reply that qualifies the '1s.' tak1ng it no longer in the sense of "1dent1ty' but a new sense, 'partaking." Socrates suggests that we "partake of" several unique Forms, being 1dentical with none of them. That is, wo can partake of Likeness and also Unl1keness. I can. for example, be 11ke other men and unl1ke beds. By partaking of Man I also partake of Llkeness with respect to myself. Or if another individual partakes of the Form Man, we partake of. Ilkeness with respect to each other. I can partake of more than one Form and so also partake of Unl1keness: I can partake of the Form Justice, whereas a 
bed cannot--so the bed and I partake of the Form Unlikeness with respect to each other,. What seems contradictory is not when qualified in this way. However, if one could show that Unity Itself 1 s Many or that Ifkeness Itself is Unlike, that would be strange. The paradox that Zeno has presented is no paradox at all, contraries in particulars can be explained by the Forms. Th1s might seem like an adequate answer that Socrates glves, however, Parmenides presses him for clarity, exactly what does 1 t mean to 'partake'? With such a request Socrates abounds w1th varlous 11teral interpretat1ons, none of wh1ch prote sat1sfactory. Socrates has $1 \mathrm{mplied}$ that Forms are separate from partlculars and that the unique individual Forms are also separate from each other-aor at least he has not pointed out to Parmenides that these are false assumptions. It seems, then, that there is a gap to fill and if some 'partaking' fills 1t that notion should be made as clear as possible.

Socrates first suggests a l1teral interpretation of the word 'partake,' that being, 'have a share (of).' Th1s leads to problems for if one has a share of a Form. does one have the whole Form or only a part of 1 t? If particulars are separate from the Forms, then the Forms are separate from themselves (which 18 absurd). A part1cular cannot possess the whole Form because then 
1t would be all used up. If you say that each particular may possess a part of the Form, strango things occur (for example, the Form Small would be larger than its part in the part1cular).

Parmenldes then suggests that taking the literal meaning of Form would be no better. For if one st1ll maintains that Forms are indeed quite separate from the particulars, then, in this case, an infinite regress will occur. If one looks at a number of things and they all look large and that Large is separate from the things looked at, and further if the large things and that spec1fic 'lo0k' all look large, then there 1111 be another Largeness by virtue they all appear large. And then one could look at all of those and find yet another Form Large and so on. 21

Socrates wonders, then, if Forms might be taken as thoughts. Although 'looks of Largeness' may be infinitely duplicated a thought which can only be in minds might escape the difficulties. Parmenides could, I think (and so also Tumbull) 22 have given some of the criticisms of the above argument once more, but, to aroid duplication and show further problems, Parmenides shows that in this case (one Form being the aame in all) would lead one to think either that everything thinks or that there must be thoughts which are not thought--the latter belng contradictory and the former strange. David Keyt belleves 


\section{(4)}

this argument to exinibit the 'fallacy of division', "It is as bad as arguing that since Forms are inteiligible entities... and things share in Forms, each thing 18 an intelligible ent1ty."23 However, fallacy or not, the suggestion of Forms as thoughts (as long as Forms are taken as being separate)--'thinking \& thought'-could run into the same difficulties as 'seeing a look.' Next Socrates suggests that Forms are patterns in reallty and that particulars are likenesses of thein. Parmentdes wonders if the Forms would not in turn be 11 ke their coples; that 1s, would not the Forra and its coples have the same character? If th1s is so and if one further takes 'being 11ke' as 'partaking of one and the same form' then an infinite regress occurs. (This argument is closest to Aristotie's Third Man.)

Finally Parmenides shows that if the Forms are steadfastly separate from particulars then there is no certain knowledge of the Forms, nor can there be. He 
st11l agree, a) Forms must exist--lest we have nothing upon which to $f 1 x$ our thoughts, and b) 'partaking of' must be explained in some other way--for as long as the gap remains, 11ttle or no sense is made of the notion. (One might, then, be led to belleve that at least another attempt will be forthcoming.)

Beginning at 1350 the teacher tells the student that he must go through a preliminary exercise, a difficult one. The exercise consists in taking a notion, drawing all that can be drawn from 1 and then taking the contrary of that notion and all that follows from 1t. After such a ritual the student w1ll be more apt at definition. The exerolse w1Il show that there is a 'log10' to be discovered in the realm of Forms, that what the young Socrates originally hint,ed would constitute a parador (one being Many, etc.) 1s, once again, only a paradox or appearances-a certaln peculiarity of our language (as will be further expanded upon with reference to toher dialogues later). Parmentdes 18 begged to give an example of such an exercise and Arlstoteles (Aristote's namesake?--belng 
any entity in each of the Bypotheses (simultaneousiy 'The One,' any speo1f10 'Porm,' ang epec1f1c 'art1cular')..$^{24}$ Such a notion hardly fits with what is actully found in the Hypotheses; that is at times only 'The one' can be meant, at others only a 'Form' can be meant, and at still other times a 'particular' must be what 18 being referred to. Hans Bochol contends that the 'one' is taken throughout strictly as meaning individual Forms, saying, "In short, in the second part of the dialogue the Idea is exclusively called the one for the same reason that the whole dialogue 18 called the Parmen1des", since Parmenides is dealing with individual Forms in the first part, he must be dealing with them in the second. ${ }^{25}$ Again. I find little credence in this theory for reasons given above (and will be shown further in Chapter III). Cornford, on the other hand, does allow for a shift in meaning of the 'one' and comes closer to my interpretation. ${ }^{26}$ I tend to sumparize the Hypotheses in this way, I. Assuming 'One' there is no intelligibility, the 'one' is without 'predicates' and being. II. Assuming 'Orie 1s' there is intelliglbility, the one is with infinite 'predicates', Forms combine and are generated in certain weys being intell1gible, particulars become intelligible. III. Assuining 'One $18^{\circ}$ as a 
others being Forms and particulars made intelligible. IV. Assuming 'One' others are not a plurallty of 'ones' and therefore unintelligible. $V$. Assuming a 'one-entity as non-existent' such a unity (particular) is intelligible and has the possiblilty of becoming. VL. Assuming the 'One as non-ent1ty' there is no intelliglb1lity, nothing. VII. Assuming the 'One as non-existent' (having no 11mit) then others (Forms) have only the appearance of limit, 11keness, etc. VIII. Assuming the 'One as non-entity' others will be nothing, having not even the appearance of anjthing. Or, of all elght Hypotheses, in shoxt. The Many causes the one to be intelliglble; the one causes: the Many to be intelligible. One without many is nothing; many without one is nothing. That the one cannot be without the Many and the Many cannot be without the one is not a contradiction or a silly notion, that is just how it is in reality. Now, having shown the context in which the Third Man argument appears, we are ready to discuss the 'third man' himself (providing we can agree on just where he 18).

\section{The Third Man Argument Itself}

All commentators agree that tha Third Man is found In the Parmenides. As we have already seen in Chapter I. Turnbull found what I have called the 'second' Th1 rd Man 
Implied at 130A-130E. But what about the 'third' Third Man? Problems, as stated earlier, prevail. Where is it and in how many forms? Some commentators (Francis Cornford and Marc Cohen) 27 find it at $132 \mathrm{~A}-\mathrm{B}$, although Gregory Vlastos and Colin Strang 28 recognise $132 \mathrm{D}-133 \mathrm{~A}$ as a vension of it (but in no important respect). Taylor seoing it twice, thinks the former is against particlpation, the latter against copying. 29 And, finally, where most think it is (132A-B), Turnbull thinks it 1sn't, he thinks that it does not really appear unt1l the passage at 1320 133A. 30 And last, and least, it should be mentioned that P. T. Geach has a version found nowhere in the Parinenides. 31 since Taylor arid Turnbull go to considerable length to show their points perhaps these should be considered before venturing on. And although in the end I shall agree with the latter, the symbol1sm used by the others (save Taylor who uses none and Geach who eloquently avolds any passage, in the dialogue), on the passage at $132 \mathrm{~A}-\mathrm{B}$ w11l pretty much do for the passage at 133A. But the difference between $I 32 A-B$ and $133 A$ is at least somewhat sitnificant as Turnbuil shows. 32

The Precise Location of the TMA

According to Taylor the Third Man Argument is found at $132 \mathrm{~A}-\mathrm{B}$ and at $132 \mathrm{D}-133 \mathrm{~A}$, he finds both hinging on the relation of particulars to the Forms. However, the latter argument deals specifically with the Copy Theory (that 
particulars are coples of Forma) opposed to the first that deals with 'participation' in general. 33 In the first argument it is assumed that there is only one reason for belleving in the Forms and that is the fact that several things we percelve have some common character, there is one Form which they all participate in or partake of. Now Parmenides does a curlous thing, he assumes that the character (Form) itself possesses its own character (Largeness is Large), making it a thing (a substance capable of having predicates in Ar1stotle's terminology, and here Taylor accepts Aristotle's critlc1sm-whereas I do not in Chapter I). Then he asks if it would not be right to say that these two things (particular and Form) have something in common. That which they have in common surely cannot be one or the other, hence, it must be some th1rd character, Form Largeness, 34 and 1 must appear large along with the particular and Form Largeness implying st1If another Form Largeness and so forth.35 It 1s with the translation of th1s argument that Turnbull disagrees. The two agree on what the argument at $132 \mathrm{D}-$ $133 \mathrm{~A}$ is designed to meet, that is, it shows the problems involved when particulars are taken as coples of Forms and if 'I1keness' works both ways and if it is by virtue of some Form that things are alike, then a regress ensues. (Taylor tries to avold this "third man" by insisting 
the relationship is asymmetrical, 36 but this will not provide an escape as I intend to show in the next chapter). Turnbull agrees with Taylor that this is the Third Man Argument and very near the one Aristotle presents. The former (Parmenldes 132A-B) cannot be because there is not even a first man.

Turnbull finds the argument at $132 \mathrm{~B}-\mathrm{C}$ as that showing what happens when the notion of 'Form' is taken too 11terally. Turnbull translates the passage leaving in the signiflcant Greek terms:

Parmenides I think that your reason for thinking each form (eldos) to be one is this. When many seem to you to be large, there seems to you, as you look at (1dont1) them all, some one form (1dea) which is self-same; hence you think that there is one Large. Socrates That's true. Parmenides If, in your mind's eye, you look at (1deis) the Larga 1 tself and the other larges-all of them--in the same way, will not yet another large appear to be ore, a Large which is required for all of these to appear to be large? Socrates So it seems. Parmenides Thus another form (eldos) of Largeness w111 appear, having come to be alonside the Large 1tself and those that partake of 1t. And then another along with all of these by which all of these vill be large. So each of your forms (eldon) will be by no means one. but unlimited in multitude. 37

Turnbull describes the Greek words for Form in the following way:

The Greek words are 'eldos' and '1dee', both derivatives from $a$ verib whose second aorlst Infinitive is '1dein' and whose first person singular present indicative is 'eldo'. By 
Plato's time the verb had no employment in its present tense. But ita employed forms admit of a double meaning. In the second aorist, it has the meaning of 'see' or 'look at'. In the perfect it has the meaning of 'know' (possibly from the commonplace that what one has seen he knows). "Idea', of course, derives from 'ide1n', and 1ts common or, if you please. 11teral meaning is 'look' or 'appearance', as in the phrase 'the look (appearance) of a thing'. 'Eldos' derives from 'eido', and 1 ts common meaning is 'that which is seen' or 'shape'.38

The passage at $132 \mathrm{~A}-\mathrm{B}$ can be understood in the sense that 'look' also appears in English with a double meaning; that is, it acts as both a verb ("Look at that:") and as a noun (Tumbull's example being, "You should have seen the look on his face.") In some sense, then, a 'look' can be seen. The trouble is that the 'look' does not exist apart from that which has the look. 39 And if Forms are separate, then there w1ll be an infinite regress. Aristotle's argument desls with 'visibles' or 'particulars' and it is because there are two things (Form and particular) that a further character is needed. In this case one has a Form and a character appearing in the argument (large). Further, Arlstotle nowhere says to 'look in your mind's eye..40 If 'look' were not introduced into this particular argument at $132 A-B$, there would be no need for a 'this man.'

What the two arguments do have in common, of course, is the introduction or assumption of some sort of 'selipredication' and an infinite regress. And although the 
former argument ght be cailed a Third Man Argument, the latter is more deserving of that name. W1th that point granted, let us proceed to formalizing the argument so as to determine 1 ts validity.

\section{Validity of the TMA}

Ever since the year 1954 when Gregory Vlastos. Introduced his step in formalizing the Third Man Argument as It appears in the Parmenides showing 1t to be formally a non-sequitur, ${ }^{41}$ even more commentators have become interested in the argument pronouncing upon it alternations. of various sorts. There had always been some queation as to whether or not the argument was indeed Inval1d, but the amblgulty was usually resoliswd by attempting to see if Plato revised or rejected his sheory (1f he did, the argument was val1d; if he did not, the argument was not val1d). The 'modern way' of dealing with arguments is to put them in symbolic form and then by a host of rules determinine whether that which is shown following fror the premisses actually should. Vlastos was, apparently, the first to perform such an operation of the Th1rd Man (dealing mostly w1th the passage at 132A-B although recognizing, symbollcally at least, the parallel or 1t in the pasgege at 132D-133A). The argument is valid formally only if certian 'suppressed premisses' come to the surface and viastos proceeded to show just 
what those were. Opening the door to symbolic representation and bringing in justification of something called 'self-predication,' Wilfrid Sellars, Colin Strang, and Harc Cohen 42 (and to a less extent st111 others) attempted the modern way with the TMA, trying to improve upon Vlastos' step toward formulation. Since 1t was Vlastos who started 1t all, I shall attend to hlm f1rst. Vlastos gives the first step at 132A in this way:

(AI) If a number of things, $a, b, c$, are all $F$, there must be a single Form F-ness, in virtue of which we apprehend $a, b, c$, as all $\mathrm{F} .43$

('F' is taken to stand for any discemible character or property.) The next step is this:

(A2) If $a, b, c$, and $F$-ness are all $F$, there must be another Form, F-ness 1 , in virtue of wh. 44 ch we apprehend $a, b, c$, and F-ness as all

The corclusion (A2) asserts something more than what is found in the first step (AI), namely, that F-ress itself is among those things which have the property, F. Vlastos conjectures that Plato must have been thinking of something more than the steps he gives, since Socrates does seen to take the argument serlously. vlastos looks for suppressed premlsses and credits the first one he Ilnds to Taylor, although he belleves Taylor never drew out all of 1ts implications. This secret premiss Vlastos calls the 'Self-Predication Assumption', 
(SP) Any Form can be predicated of 1tself. Largeness is itself Iarge. F-ness is 1tself F. 45

Vlastos suggests that Plato came very olose to stating this in the passage when he sald "W1Il not a single largeness appear once again, in virtue of which all these ('Largeness and the other large things') appear large?" (Parmen1des 132A). This seems to indicate that Largeness 1tself appears large. 46 spiro Panaglotou, in commenting on Vlastos' interpretation, goes so far as to say that 'viewing' 1tself entalls the notion of self-predication, that Vlastos did not need to go off looking for some other textual evidence of it (as he does do) $:^{47}$ The premiss alone, however, 18 et1ll not enough to yleld the needed result so Vlastos seeks next to fustify the consequent of (A2) coming up with what he calls the 'Non-Identity Assumption',

(NI) If anything has a certain character, it cannot be Identical with the Form in virtue of which we apprehend that character. If $\mathrm{B}^{\mathrm{x}}$
is $\mathrm{F}, \mathrm{x}$ cannot be 1dentical with F-ness. Simply put, if the largeness of a thing is not 1dentical with that things, then if Largeness is large, 1ts largeness also cenrot be 1dentical wh Largeness. The two additions are inconsistent with each other and 1t is just for that reason we can generate any conclusion we like. Peter Geach goes so far as to say that the two are contra- 
dictory, "For no $F$ is (1dentical with) F-ness' is equivalent to 'Foness is no $F$,' which is the direct contradiction of 'F-ness is 1tself an F." 49 (It is, of course, necessary to be able to subst1tute a Form for $x$ in any case.) This further leads vlastos to belleve that Plato could nerer have been aware of what these premisses were for he is not the sort of philosopher to present an argument with inconsistent premisses leading to a trifling conclusion. 50 vlastos does think, however, that these two premisses are just those necessary to to bring on the regress. But are they? If (SP) and (NI) are actually required then the conclusion must be logically Inconsistent, but 1 is not. But as Marc Cohen sees (and no doubt others have seen) the conclusion should be understood to be the contradictory of the notion of the Forms cited at 132A, that 1s, It should read, "And so there will no longer be one Form for you in each case, but infinitely many."5I The result: no inconsistency. An inconsistent premiss set 18 not necessary for the conclusion.

The above being the case, Sellars, Strang, and Cohen have attempted to formulate the argument with a consistent set of premisses. Sellars, perhaps, is nezt In Iine. First of all Sellars does not think that (SP) 
and (NI) necessar1ly need to be taken as contradictorles 52 and further points out problem wh the expression of 'F-ness' in Vlastos' formulation of the argument. There seem to be two syntactic categorles (and a comblnation of the two) to which we could possibly assign expressions which come about from 'F-ness' when 'F' is replaced by one of 1ts substituends, these being:

(1) a representative symbol or name--the proper name of a Form, 'Largeness,' for examplef or

(2) a variable proper allowing us to quantify in respect to the subst1tuends for F-ness. "For all Largenesses

(3) a combination of "modes of variability" and "representat1ve varlables"--whlch means 'F-ness' stands in place of not a class or mere names of simple Forms, but a class of rariables.

It is the latter view that sellars takes, finding that Vlastos errs in his use of (SP) and (NI) by allowing free occurrences of the stana-in varlable 'F-ness. 53 The remedy, it seems, is to add quantifiers and Sellars does:

(SP') All F-nesses are F.

(NI') If $x$ is $F$, then $x$ is not identical with

But, now, to make the argument complete, sellars adds two further premisses:

(G) If a number of entities are all $F$, there must be an F-ness by virtue of which they are all F.

(P) a. $\underline{b}, \underline{c}$, etc., particulars, are F. 55

So now fresh forms can be generated by a consistent set of premisses: (P) gives the supply of particulars and 
(G) provides the generation of a Form by virtue of which they are all called F. (NI') tells us that none of the Fs in the group $1 \mathrm{~s}^{2}$ identical with the Form $(G)$ has generated, and $\left(S P^{\prime}\right)$ tells us that the Form just now generated is also an F; and this goes on forever.

Marc Cohen finds that there is a problem with Sellar's (NI') because 1t w1ll not generate the regress allowed for at 132B. Sellars' formulation seems to 1mply that F-ness 2 can never cover ang of the particulars that F-ness does. Cohen suggests it might be better put this way.

(NI $\left.{ }^{2}\right)$ if $x$ is $F$, then $x$ is not identical with any of the F-nesses by virtue of which

In 1955 viastos gave a reply to sellars claiming that subst1tuends for 'F-ness' are not properly varlables but rather proper names of the Forms, whlch means that the premisses are in fact only (SP) and (NI) forming an inconsistent set. 57 In 1969 vlastos admitted that he would be more impressed with a consistent set of premisses rather than an inconsistent set but that sellars' formulation simply did not fit the text. Sellars' (G) Implies that there is at least one Form corresponding to a given thing, when throughout the dialogue Plato means it to be exactly one. It 19 only in this way that the uniqueness thesis can be denied. Vlastos changes Sellars" $(G)$ to $\left(G^{1}\right)$, 
$\left(G^{1}\right)$ If a number of entities are all $\mathrm{F}$, there must be exactly one Form corresponding to the cheracter, $F$, and each of those entities is F by virtue of participating in thet Form. 58

By adding this ( $G^{l}$ ) to his own slightly reformulated (AI) and (A2) Viastos (1n 1969) finds an inconsistent triad. A similar notion had been put forth by Anders Wedberg some fourteen years earlier,

(1) A thing is $Y$ if and only if it participates In the Idea of $Y$-ness.

(11) An Idea is never one among the objects participating therein.

(111) The Idea of $Y$-ness is a $Y .59$

Wedberg's (11) is simllar to Vlastos' (NI) and although (11) and (111) are not inconsistent, when added to (1) which is necessary, the three do form an inconsistent set.

Colin Strang is another commentator eager to make the set of premisses needed for the TMA a consistent set. He, like Selzars, looks for the answer in the shift of. meaning of "one." His argument is this:

1. Let there be several (a set of) A's; call them set I.

ASSUMPIION, (OM) Given a set of $A^{\prime} s$, they participate in one and the same $F(A)$.

2. By $O M$, the $A$ 's of set I participate in one and the same $F(A)$; call it $F$ (A).

3. There 1 s one and only one $F(A)$.

CALL TEIS (U) short for the Uniqueness Thesis ASSUMPTION: (SP) $\mathrm{F}_{-}$(A) is an A. ASSUMPTION, (NI). FI A) is not a member of set. $I$. 4. $B y S P$ and $N I$, the $A^{\prime}$ 's of set I together with $F_{1}(A)$ form a new set of A's; call 1 t set 2. 
5. By OM, the A's of set 2 part1cipate in one and the same $F(A)$; call it $F_{2}(A)$.

ASSUMPTION: (SP) $\mathrm{F}_{2}(\mathrm{~A})$ is an $A$ ?

ASSUMPTION, (NI) $F_{2}^{2}$ is not a member of set 2 .

6. By NI, $F_{2}(A)$ is another $F(A)$.

7. Moves 4-6 may be repeated again, and indeed inderinitely.

8. Therefore there are an infinite number of $F(A)$ 's.

9. Therefore not-U.

Strang then draws out two further 1mplications:

10. But U (1.e., not-not-U)

11. Therefore either not-OM or not-SP or not-NI. 60

Strang points out, in the passing, that although one needs to work to surface the (SP) in the version of the argument at $132 \mathrm{~A}-\mathrm{B},(\mathrm{SP})$ is less concealed and plays a more prominent role in the argument at $132 \mathrm{D}-133 \mathrm{~A}, 6 \mathrm{I}$ This is true and 1t makes me think how much simpler it would have been for Vlastos had he considered that argument for his exercise as his prime interest--but, again, the two are very close. Strang's argument, above, is somewhat appealing but again shifts between what strang calls the (strong $O M$ ) and the (weak OM). Th1s does not seem to be warranted by the text and Mare Cohen brings an alternative which would allow for a consistent set of premisses and the same sense of (OM) throughout. If 1 t works, and I think 1t does, Cohen's formulation nas more merit.

Cohen begins his search for the most desirable formulation (quas1-formulation -- no commentator has put the argument in strict symbolic form) of the Third Man 
by attempting to revise seliars' (G) which was, If a number of entities are all $F$, there must be an F-ness by virtue of which they are all F. And, of course, Vlastos had changed 1t to (GI), If a number of entities are all F, there must be exactly one Form corresponding to the character, $F$; and each of those entities is $F$ by virtue of particlpating in that Form. Vlastos (GI) is rejected In hopes of stating $(G)$ such that no inconsistency would appear in the premisses, Cohen makes a number of attempts (too numerous to consider here) to find just the right (G) whon he finally decides that some definitions would be in order. And those, I think, should be given!

(DI) An obfect is anything of which ' $F$ ' can be prealcated.

(D2) A particular is an object in which nothing (can?) participates.

(D3) A Form is an object that is not a particular.

(D4) An object is an object of level one if

(a) All of its participants are of level n-l or lower, and

(b) All objects of level $n-1$ or lower participate in it.

(D?) $\Lambda$ set of objects is a set of level. $n$ if $1 t$ contains an object of level $n$ and no higherlevel object.

(D8) A set of level $n$ will be said to be a maximal set if it contajns every object of level $m$ for every $m \leq n$. 62

To all of this Cohen adds an axiom and two theorems to arrive at his best alternative for $(G)$,

(OM-Axlom) For any maximal set there is exactly one Form in which all and only members of that set participate.

(TI) No object is on more than one level. 63 
The above he gets from (D6), (D8) and the (OM-Axiom). Now Cohen thinks he is ready to announce his $(G)$, which is, by the way (GII) for him by this time:

(GII) For any set $a$, there is exactly one Form participated in by all and only members of the lowest-level marimal set which contains every member of $a .64$

St1ll, alas, there remains a problem, the Form generated cannot be said to be over, in the sense that we want it to be, that 1s, one over many. What we have is a one over one. What we need is a form 1mmediately over and not the set itself, but each of the members. This is the way Plato must have meant it. It is Cohen's (OM-Axiom) which contains the flaw and to revise it he needs even more definitions:

(D9) $x$ is over $y=d f y$, or if $y$ is a set, every member of $y$, partic1pates in $x .65$

But this makes the relation not one-one nor a one-many. So on tos

(DIO) $x$ is immediately over $y=d f x$ is over $y$ and $x$ is over all and only those sets whose level is equal to or less than that of $y .66$

This means that while the over relation may be many-many, the immediately over relation is one-many (which is what we want). Cohen 18 ready for his revised Axlom:

(IOM-Axiom) For any set of Fs, there is exactly one Form 1mmediately over that set. 67

Thie, by the way, is equivalent to (GII) and entalls the 
(OM-Axiom). To this add one more theorem and Cohen 18 ready for his argument,

(T3) If $x$ is immediately over $Y$, then the level
of $x$ is one greater than the level of $y .68$

The above theorem is derived from definitions 6-10. And now, at last, Cohen's final version of the TMA,

1. Let $A$ be any set of Fs (of level $n$ ).

2. There is exactly one Form Immediately over A, call 1t 'F-ness I'. (I). (IOM-Axiom)

3. F-ness I is of Ievel $n+1$ (1), (2), (T3)

4. F-ness I is not a member of A. (1), (3), (TI), (D7)

5. A $\nabla$ (F-nessI) is of level $n+1$. (1), (3), (D7)

6. There is exactly one Form immediately over A $V$ (F-ness I), call 1t 'F-ness II'. (5), (IOM-Ax1om)

7. F-ness II is of level $n+2$.

8. F-ness II is not a member of $A \vee(F-n e s s I)$

9. F-ness II $\neq$ F-ness I

$(5),(6),($ T3)

-

- etc. 69

This argument ylelds exactiy one Form for the set under consideration at each stop, the (IOM-Axiom), revised from the (OM-Axiom), is consistent too with there being more than one Form over the set w1th which we start. Further, in this argument (SP) and (NI) do not come in as bona flde premisses-as 19 true also in the passage at Parmenides 132A-B. Instead (SP) is presupposed in the defintitions of 'Form' and 'object.' (NI) comes in as a consequence in step (4) being an instance of the theorem that a Form is not a member of the set it is over. 70

Cohen's interpretation directs one's attention to 
the 'one-many' problem which persists in the Parmenides. As Cohen says,". . It 1 s the point of the TMA to show that the one-over-Many princ1ple, far from supporting the Un1queness thesis, leads to 1 ts denlal." ?l What one must do, of course, is this, reject the 'one-over-many' showing how the 'one-mang' is intelligible (as I interpret Parmenides as dolng in the second part of the Parmenides). Let it suffice for now to say that the argument is valid. And since the argument (both versions in the dialogue) involves 'self-predication,' and the original-copy argument brings in Forms as 'paradigns' and both versions deal w1 th "exemplification," it right be woll in order to discuss each of these notions.

Self-Predication

Since Vlastos was first to bring the principlo of Self-Predication to light, pexhaps it is best to consider just what he has to say about 1t. First, however, I think It undoubtedly true that 'self-predication' does come into the Third Man Argument(s) of the Permenides (Cohen's version coming closest to the passage). And if I am correct in thinking that the argument is not against what plato really held, but rather the argument is used as a diuretic to purge others of the over-simplifled notions therein, then one should not find 'self-predication' elsewhere in Plato's works, or, if it appears to be there (as it must 
have for anyone to assume 1t), there must be some other explanation of the language used. Vlastos himself does not think that Plato ever intended 'self-predication' (further, that he did not even recognize 1ts existence In the. Third fan, to which I find the contrary), however, he thinks 1 t does eppear to be 1 mplied by his Degrees-orReality Theory and by h1s Copy-Theory,

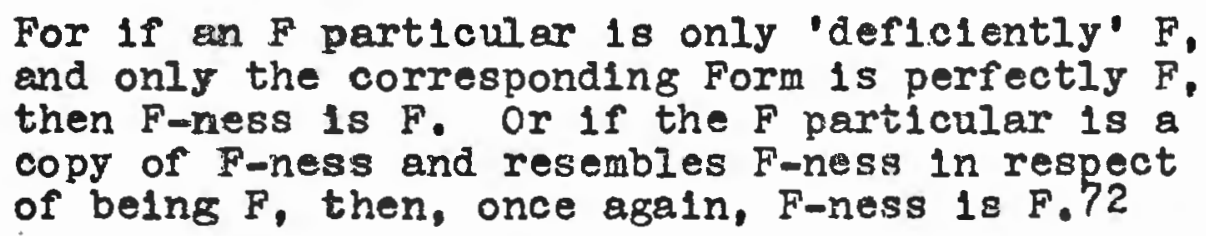

Th1s 1s, of course, the way the copy theory is at least as presented in the Third Man at 132B-133A (and I think hardly, evidence that Plato held it). But Vlastos thinks also that various statements about particular Forms found throughout Plato's dialogues imply this assumption. In the Lysis (2I7D) Socrates says that when a man's hairs, have turned white "They have become such as that which is present in them, white through Whiteness." Th1s seems to Imply, Vlastos thought, that the white halrs have the same quality that whiteness 1taelf does. Another exanple may be taken from the Protagoras $(300 \mathrm{C}-D)$ : Socrates says, "What other thing could be holy, if holiness isn't holy"-implying that holiness is holy. Also in the Phaedo (I00C) Socrates says, "If anything else is beautiful, beside Beauty 1tself." and the symposium certainly gives tho 
implication that Beauty is beautiful--more fair than any of its instances. Vlastos does aimit that not all Forms are open for 'self-predication' f for examples Change, Becoming, Perishing, and Moring. To say that Chango changes, Becoming becomes, Perishing perishes or that Movement moves clearly goes against what Plato means as Form in the first place, since Form are to be absolutely perfect being with no changes.73 If one could get rid of 'self-predication' then the 'third man' would not ar1se, But it appears that we do have 1 t.

Paradigmatism.

Much has been sald about Forms as paradigms. Plato certainly does imply that Forms do stand as archtypes as is clearly evident in the Cratylus (389B) where if a shuttle is broken, it is to the Form shuttle that we look, not the broken particular, when we make another. Forms are presented as paradigms in the Republic at $402 C, 472 C-D, 484 C-D, 500 E-501 C, 510 A-B, 520 C, 540 A$, and in the Phaedrus at $250 \mathrm{~A}-\mathrm{B}, 251 \mathrm{~A}$, and in the Timaeus at $29 \mathrm{~B}-\mathrm{C}, 37 \mathrm{C}-\mathrm{E}, 39 \mathrm{D}-\mathrm{E}, 48 \mathrm{E}-49 \mathrm{~A}, 50 \mathrm{C}, 52 \mathrm{C}, 92 \mathrm{C}$, and at numerous other passages throughout Plato's texts. To make some sense out of the above analogies have been drawn, the most popular one being the analogy of the Standard Pound; Goach uses it to show the relation of Forms to partioulars. He says that the Standard Pound 
must relgh a pound no matter what it welghs, whereas the particular pounds are welghed against the Standard Pound. more or less welghing a pound. The standard Pound is not, however, welghted against 1tself. We say that the Standard Pound $1 \mathrm{~s}$ a pound or welghs a pound analogously. Plato did not think of Forms as 'attributes' as the analogy should show: Forms are the standards to be measured up to. Geach thinks too that 'self-predication' involved in the Form as standard is simply, once more, analogous to the predication we use of particulars. 74

Vlastos does not find much meaning in this word 'analogous' and the Standard Pound "welghing a pound no matter what $1 t$ welghs" (as Geach put.it) is misleading. We would be inclined to look for some rurther standard Pound to welgh the first one against (a Third Man Argument of sorts would occur). 75

Colin strang, who by far has the most interesting account of paradigmatism, finds that the TMA in the Parmenides carries along with it the notion of Forms as paradigms. He thinks that Plato was aware of selfpredication and further' if 1 t goes, so too do Forms as archetypes. Strang defines a paradism as that which has the character perfectly, and this 18 certainly selfpredication. If 'self-predication' is rejected (as it must be since the TMA is a valid regress argument) there 
18 nothing left of the Form to serve as a standard of anjthing. 76 Forms are invisible, howerer, so perhaps we should look for an invisible analogy, the Imperial Standard Yard (opposed to the Standard Yard which was once damaged and 1 ts replacement was constructed according to 1ts certified copies:),77 "1t 1s the length the standard bar has under the conaltions spec1fied."78 But there remains a problem even with this. If Forms are invisible, how can particulars be coples resembling the Forms? (Further, as Strang points out, other problems arlse with the Imperial Standard Yard, it was not that looked to for the making of the Standard Yard, only coples some years later; and 1t could be redefined or changed if the standard bar shrinks as it just possibly might. $)^{79}$ There simply does not seem to be any way to keep Forms as paradigms, if one makes the assumptions that strang does.

Exemplification.

In the Third Man Argument in the Parmenides Socrates is trying to find a meaningful way of explaining 'partaking of'--or the more common way of putting 1t, 'being an instance of.' Gllbert Ryle thinks that 'exemplificetion' is not to be trusted end that furthor no sense can be made of "being an instance of." To do this he presents an 
argument which leads to an infinite regress showing that something must be wrong with 'exemplification' 1tself. 80 H1s argument can be seen more clearly, I think, if we put it in this way:
(a $18 \mathrm{~T}$ ) exemplifies $\mathrm{E}_{1}$
(b $18 \mathrm{~S}$ ) exemplifies $E_{1}$
(two instances of exemplifying
$\left[\begin{array}{lll}{[a} & \left.\text { is } T) \text { exemplifies } E_{1}\right] \text { exemplifies } E_{2} \\ {[(b} & 18 \mathrm{~S}) & \left.\text { exemplifies } \mathrm{E}_{1}\right] \text { exemplifies } \mathrm{E}_{2}\end{array}\right.$

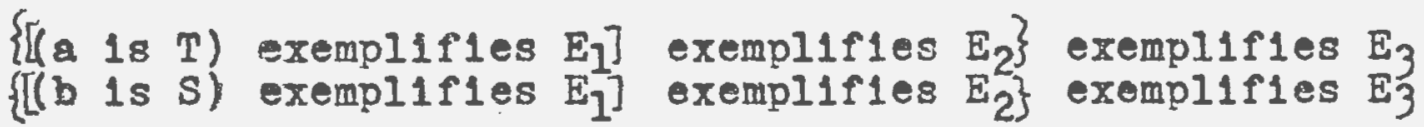
$\left\{\left[(b\right.\right.$ is $S)$ exemplifies $\left.E_{1}\right]$ exemplifies $\left.E_{2}^{2}\right\}$ exemplifi

That 1s, if we take Exempiffeation as the Form over and above, say, Tallness, instead of TaIness once again (as 1t happens with Largeness in the TMA at Parmenides 132A-B) we st111 111 have an infinite regress--a duplication of the same Form. If this is so, Ryle concludes, it is 1llegltimate to speak of 'exemplification' at all. 81 Does this mean, then, that there is no possible way to arold the "third man'?

We have shown that the TMA 13 loglcally valid, that 1t does involve self-predic: on, that forms as paradigms have rallen, and now an argurent that proposes to show that 'being an instance of' is Impossible. Look to Ghapter III. 


\section{Notes}

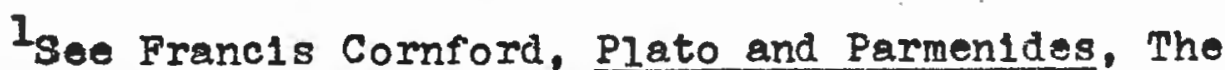
Library of Liberal Arts (New Yorki The Bobbs-Merrill Company, Inc., 1957), p. 63.

$2_{\text {See W. C. Runciman, Plato's Later Eolstemology }}$ (Cambridge, England. The University Press, 1962), pp. 1-5, G. E. L. Owen "The Place of the Timaeus in Plato's D1alogues" and Harold Cherniss, "The Relation of the Timaeus to Plato's Lator Dialogues," both in Studies in Plato's Metaphysics, ed. by R. E. Allen (New Yorki The Eumantites Press, 1965).

3see Owen, "The Place of the Timaeus."

4A. E. Taylor, Plato. The Man and His Work (New York, The Human1t1es Press, 1949), pp. 350-351. Also see: H. G. Runciman, "Plato's 'Parmenides," In Studies In Plato's Metaphysics, ed. by R. E. Allen (New Yorki The Humanities Press, 1965), p. 167, for a tidy summary of several other interpretations see pp. 167-176.

5see Gilbert Ryle, "Plato's Parmenldes," in studies in Plato's Metaphysics, ed. by R. E. Allen (New Yorks The Euman1t1es Press, 1965).

61111am F. Lynch, An Approach to the Metaphysics of Plato through the parmienides Thashingtons Georgetown UnIversity Press, 1959), pp. 42-43.

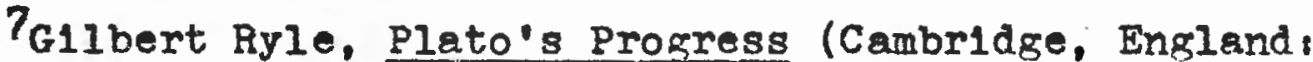
The University Press, 1966), p. 294.

Bryle, Plato's progress, p. 287.

9'Ryle, Plato's Progress, p. 204.

10 Ryle, Plato's Progress, p. 290.

11 Bjle, Plato's Progress, p. 291.

12G. E. L. Owen, "Notes on Ryle's Plato," In Byle: Modern Studies in Philosophy, ed. by 0scar P. Wood and George P1tcher, A Doubleday Anchor Original (Garden City, New York: Doubleday and Company, Inc:, 1970), p. 371. 
${ }^{13}$ See Cornford, plato and. Parmenides, p. 64. 14 Ryle, Plato's Progrtess, p. 292.

15cornford, Plato and Parmenides, pp. 80-81.

16 Taylor, Parmen1des, Zeno and Socrates, in Philosophlcal studies (Freeport, New Yorks Books for Librarles Pres\$, 1968), pp. 65-66.

17Taylor, The 'Parmentdes' of Plato (Oxford, The Claredon Press, 1934), p. 111.

${ }^{18}$ I w1Il attempt to show this in Chapter II. For the view that the existence of the Forms is not assumed in the Parmenides sees J.M. E. Morarcsik, "The Concept of Existence and Self-Exemplification in Plato's Phllosophy." (Standford University), unpublished.

${ }^{19}$ It might well be that Parmenides' 'One' is Matter-I remain unresolved on this matter. See Leonardo Tarán. Parmentdes: A Text w1th Translation, Commentary, and Critical Essays (Princton, New Jersey, Princeton University Pross, 1965$)$.

${ }^{20}$ Robert G. Turmbili, "Plato's Repudiation of the "Separation of the Forms in Parmen1des 1278-1350," unpubilshed, pp. 7-8.

21 I follow hore the same interprotation that Turnbull sees on pp. 27-28 in "PIato's Repudiation."

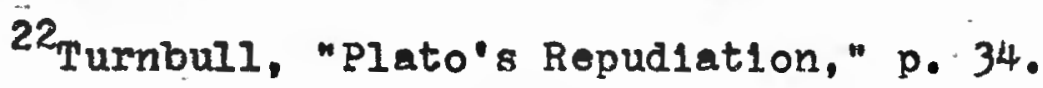

${ }^{23}$ Dav1d Keyt, "The Mad Craftsman of the Tiameus," The Ph1losophical Rev1ew (Apr11, 1971), 235. Professor Donald ZeyI of the UnIversity of Rhode Islend sees Plato arguing in just that way in the Republic: "In fact, I think in the Rop. Plato does 1mply that the things which share in Forms. by virtue of this relation, are intelI1gible entities." of course, the 1ssue at this point in the Parmenides is whether or not 'Forms' can be taken as meaning 'thoughts."

24 pp. $44 \mathrm{ff}$.

Lynch, An Approach to the Metaphysics of Plato,

25 Hans Rochol, "The Dialogue 'Parmentdes's An Insoluble Enigma in Platonism?" International Philosophical Quartexly, XI (December, 1971), 159, 
${ }^{26}$ Cornford, Plato and parmenides, pp. 109-115.

27Cornford, P1 ata and Parmentdes, pp. 87-90, Marc Cohen, "The Loglc of the Third Man," paper presented at a Symposium on Plato's Parmenides, Inst1tute in Greek Philosophy and Science, Colorado College (July, 1970).

${ }^{28}$ Gregory Vlastos, "The Thira Man Argument in the Parmen1des," In Studies in Plato's Metaphysics, ed. by R. E. Allen (Now York, The Humanities Press, 1965), pp. 241-242; Colln Strang, "Plato and the Third Man," In Plato Is Metaphys1cs and Ep1stemology, ed, by Gregory Vlastos, Anchor Books (Garden C1ty, New York! Doubleday and Company, Inc.. 1971), p. 184.

29Taylor, parmenides, Zeno, and Socrates, pp. 65-66: 30 Turnbull, "Plato's Repudiation," pp. 28-32.

$31_{\text {Peter T. Geach, "The Third Man Again;" in Studies }}$ In Plato's Metaonysics, ed. by R. E. Allen (New Yorki The Humanities Press, 1965), pp. 271-275.

32 Turnbull, "Plato's Repudiation," pp. 28-38.

33 Taylor, Parmenides, Zeno, and Socrates, p. 44.

34 v1astos' term. See "The Third Man Argument in the Parmenides:"

35 Taylor, Parmentdes, Zeno, and Socrates, pp. 45-46. ${ }^{36}$ Taylor, Parmen1des, Zeno, and Socrates, pp. 87-89.

37 Turnbull, "Plato's Repudiation," p. 25.

38 Turnbull, "Plato's Repudiation," pp. 26-27.

39Turnbull, "Plato's Repudiation," pp. 27-28.

40 Turnbull, "Plato's Repudiation," p. 33.

41 v1astos, "The Third Man Argument in the Parmen1des," pp. 233-241.

42 W11frid Sellars, Vlastos and 'The Th1rd Man," in Philosophlcal Perspectives TSpringfield, Ill, Thomas, 1907): Strang, "Plato and the Th1rd Man"; Cohen, "The Logic of the Third Man." 
43viastos, "The Third Nan Argument in the Parmenides," p. 232 .

p. 233.

44 viastos, "The Th1rd Man Argument in the Parmen1des," p. 236 .

45viastos, "The Third Man Argument in the Parmen1des," p. 237 .

${ }^{46}$ Vlastos, "The Third Man Argument in the Parmenides,"

47 Spiro Panagiotou, "Vlastos on Parmenides 132Al-B2: Some of H1s Text and Logic," The Ph1losophical 2uarterly, XXI (July, 1971), 255-259.

p. 237.

48 viastos, "The Third Man Argument in the Parmenides,"

${ }^{49}$ Geach, "The Third Man Again," p. 265. Geach, I think, makes a shift in the meaning of ' $1 \mathrm{~s}^{\prime}$ which is unwarranted. p. 241 .

${ }^{50}$ Vlastos, "The Th1rd Man Argument in the Parmen1des,"

${ }^{51}$ Cohen, "The Log1c of the Third Man," pp. 5-6.

52 Sellars, Vlastos and "The Third Man"; pp. 30-31. Largeness is not large in the same sense that particulars are large, which implies that Sellars thinks it is wrong to subst1tute $F$-ness for $x$ to begin with.

53 Sellars, Vlastos and 'The Third Man', pp. 34-35.

${ }^{54}$ sellars, V1astos and 'The Third Man', p. 36.

55 Sellars, Vlastos and The Third Man'. p. 36.

${ }^{56}$ Cohen, "The Logto of the Third Man," addenda to his footnotes, \#13a.

- Plato thinks of the particulars $a, b, c$, as being $F$ in virtuo of the flrst Furm, F-ness $I$, and all of these, in turn, as being $F$ in virtue of a second Form. Foness II. But (NI') disallows this, since it requires that there be, for each F thing. such a thing as the F-ness by virtue of which it is F. Hence F-ness II cannot cover any of tho particulars that $F$-ness I coters, and the regress w111 not develop. 
57 viastos. "Addenda to the Third Man Argument, A Reply to Professor Sellars," Philosophical Review, LXIV (1955), 438-448.

58 Vlastos, "Plato's 'Third Man' Argument (Parmenides 132A1-B2): Text and Log1c," Ph1losoph1cal Quarterly, XIX (October, I969), 289-301.

59 Anders Wedberg, Plato's Philosophy of Mathematics (Stockholm, Almqvist and Wiksell, 1955), pp. 36-37.

60 Strang. "Plato and the Third Man," p. 185.

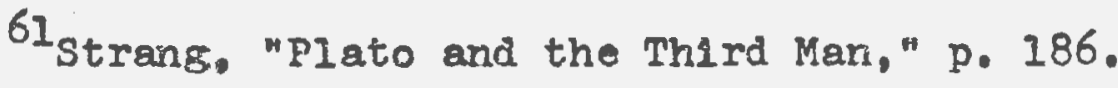

${ }^{62}$ Cohen, "The Logic of the Third Man," p. 15.

${ }^{63}$ Cohen, "The Log1c of the Th1rd Man," pp. 16-17. ${ }^{64}$ Cohen, "The Log1s of the Third Man," p. 19. ${ }^{65}$ Cohen. "The Log1c of the Third Man," p. $19 a$. ${ }^{66}$ Cohen. "The Log10 of the Third Man," p. $19 b$. ${ }^{67}$ Cohen. "The Logic of the Third Man," p. 19b. 68 Cohen. "The Log1c of the Thira Man," p. $19 \mathrm{c}$. ${ }^{69}$ Cohen, "The Logic of the Third Man," p. 19c. 70 Cohen, "The Logic of the Third Man," p. 18. " Cohen, "The Logic of the Third Man," D. 19d. 72 viastas, "The Third Man Argument in the Parmenides," p. 248 .

73viastos, "The Third Man Argument in the Parmenides," pp. 249-251.

${ }^{74}$ Geach, "The Third Man Aga1n," pp. 267. 276.

75 viastos, "Postscript to the Th1rd Man: A Reply to Mr. Geach," in Studies in Plato "s Metaphysics, ed. by R. E. Alien (New York, The Humanit1es Press, 1965), pp. 284-285. $7^{6}$ strang, "Plato and the Third Man," p. 188. 
79

77 Strong, "Plato and the Third Man," p. 188.

78 Strong, "Plato and the Third Man," p. 189.

79 strong, "Plato and the Third Man," pp. 189-191.

${ }^{80}$ Ryle, "Plato's Parmenides," pp. 106-107.

81 Ryle, "Plato's parmenides," p. 107. 
III

ESCAPING THE THIRD MAN

The Relation and the Related

It is at $133 \mathrm{D}$, if you recall, that socrates suggests that Forms are real1ty and stand as patterns to particulars, particulars belng likenesses of the Forms. Parmenides then asks if the Forms would not in tum be like the ir coples. Socrates replies, "so it seems" and the regress ensues. (It happens in a simllar way in the argument at 1328 w1th 'looks of largeness'--part1cular and Form-being Ilke some further 'look' of largeness.) The question 1s, are Forms like their coples? 'Self-predication.' Forms as paradigms, and exemplification are all 1nvolved. Although Socrates is allowed to answer, "So $1 t$ seems," what if we answer 'No"? What justification can there be (assuming that elther Plato was not aware of any justiflcation, thus saving him, or assuming, as I do, he was)? Cornford, Taylor, and Chemiss ${ }^{l}$ stana as prime proponents of an 'asymuetrical' relation holaling between Forms and particulars. That is, as Proclus (Noomplatonist) put 1t, "the copy is a copy of its orlg1nal, but the oreiginal is not a copy of the copy." 2 In other words, particular things are like each orher in virtie of a Form, 
but the Form cannot be like them ir the same manner. Taylor tries to make it more obvious with this example: Hy carte-de- viste photograph and my living face may be II ke one ancther, but the I1keness is not suck that it could be argued "This photograph is a 11 keness of you, ergo, by conversion, you are a 11keness of 1t". 3

The example shows that 'I1ke' changes 1ts meaning. Cherniss says that if 'I1ke' is allowed to be taken the way it 18 in the Parmenides, it proves "nothing can be a I1xeness of 1wage of anything whatever"4 -which woild be absurd. Taking the relation between particulars and Forns as asymmetrical rather than symmetrical, Cornford, Cherniss and Taylor hope to avold the vicious regress of the TMA. But does this 'asymmetrical' relationship remove all probiems? I think not (so too Vlastos, Ruriciman, and Hardie ${ }^{5}$, for to even admit that they are alike in any sense is to invite the regress. A copy and that of which it is the copy of are similar and similarity does work both ways.

R. E. Allen does have somewhat of a solution, I thints (as implied in Chapter I). He goes to his looklngglass and shows that Plato's metaphor does not even imply thet the particular esemble the Forms. 6 Fere Allen goes well beyond Tayicr. He gives thia example,

Consider the reflection of a red scarf in a mirror $-a$ good example of what plato understands by an imitation. It is clea.r.y false that the 
reflection is a scarf. Is it true that it is red? The reflection 18 not similar in kind to the original. Is 1t then similar in quality. If we say that it is, we face an evident embarrassment, for to say this is to say that we can predicate of reflections, which are essentially adjectival, in just the way we predicate of their originals, things which exlst in their own rlght. Scarves can be bought and sold, lost or stolen, wrapped. around the neck in winter, but I would gladly give you every lmage that has crossed the surface of my mirror, and count myself no poorer for the loos.?

Allen contends that it is all right to say that the image is a scarf--to give the image that name, however, we mean something entiraly different when we speak of the image than when we speak of the real thing. The 1mage depends entirely upon the existence of the real thing and the medium (the mirror in this example--space in Plato's metaphysics es shown in the rimgelis). And since there is such a dependence (obvlously the dependence is not the other way around--heavy dust could prevent my image from exlsting-and I would in no way be alterd), the lmage does not resemble reality, but rather it is a resemblance of reall ty. ${ }^{8}$ A reflection $1 \mathrm{~s}$ a different 'sort' (cf. the Soph1st $240 \mathrm{~A}-\mathrm{B}$ ).

Taylor's earlier example of his photograph--although It does succeed in showing an asymmetrical relation--does not have the force and added signiflcance of the mirror example. My photograph, althougin 1t mlght be sald to resemble me, does not continualiy depend upon me for its 
extstence. I could have a heart transplant, plastic surgery and even die and rot sway; still, the plcture might well remain. Not so with Allen's looking-glass, the image deperds ent1rely upon me--in a three or moreway mirror all of the 1 mages would depend upon me continuously and if I should vanish so too would my resemblances (and they could vanish without me vanishing by interference of some sort). It is because of this com plete dependence that Allen chooses to call particulars resemblances of the Forms, which is something stronger and quite different from saying that particulars merely resemble the Forms. As Allen puts 1t,

'Resemblances of' are quas1-substantial; relational entities, not relations. They siand to their originals as the dependent to the fndependent, as the less real to the more real.9

It 18, as stated earlier, quite all right to call these relational entities by the same name as their Form but predication as we understand it is not found in Plato. Vlastos has convioted Plato a bit hastily with his 'selfpredication' assumption. Plato's predicates are not what they might appear to the uncritlcal eye' The 'F-1tself' might be called $F$ but that does not imply that $F$ is indeed predicated of 1t. For proof of this he turns to the following !

Phisedo 10282

Each of the Forms exists, and the other things which come to have a share in them are named 
after [the emphasis 18 Allon's] them.

Phaedo 103E

Not oniy is the Form 1tself always entitled to its own name, but also what is not the Form, but always has, whon 1 t exlsts, its immanent character.

And from Arlstotle (although he does not grasp the significance)!

Met. A 98783

Sensible things; [Plato] sald, were all named after [Ideas] and in virtue of a relation to them; for the many existed by participation in the Ideas that have the same name as they.

Allen wishes to show that thes passages indlcate that ' . Is F' is not a common predicate but rather a 'relational' or 'Identifying' statement. ' $F$ ' is really a 'common name'--although not unirocal--the Form being designated as $F$ and the particular instances being called 'F' by being named after the Form, similar to the way in which boy is named after his father. '. . is F' is actually systematically ambiguous, in its pxinary designation it is a synonym of 'the F-1tself' and 'Founess' ('Poness is F' states an indentity of the Form) ${ }^{10}$-and in 1is derivative designetion it namss particulars indicating that they are causally dependent upon the F. Forms are exepolney causes of particulars, sharing no common attribute rith the Forms. ${ }^{11}$ Forms are the substances, partloulars are not substances with attributos. Predication is not what it seems. 
In Vlastos' recent article "The Unity of the Virtues in the Protagoras," after otudying Pleto's passages which seem to predicate not only just of Justice, but piety and the other virtues as well, Vlastos concludes that his prime example of self-predication (Justice is just) fa1ls to be 80.12 Part of the article is in response (partial) to Allen's article written some twelve yoars prior. He is not, however, wlling to grant that Allen is completely correct; 1.0., that Justice is just is a statement of 1dentity. 13 Instead, he concludes that the virtues are complementary and that when we have one of the virtues, the others are so similar we are likely to have them as well. "Justice is pious" 18 example of what vlastos now calls 'Pauline Predication' (derived from St. Paul's! Charity suffereth long and is kind"--this is not intended of a form or unitersal but rather those who have char1ty); that for once Plato is talking about groups of particulare. ${ }^{14}$ - Vlastos contends that Plato orginally gave only three instances of the (SP) principles a) that of Justice (actually, also Hollness), b) that of Boauty, and c) that of Whiteness. (a), of course, has been rejected and viastos goes on to reconsider the others in a footnote. He decides to reject "Whiteness is white" as self-predicative in the following ingtance (LyS1s 217D7mi) referring back to his previous article: 
the white halrs sre 'such as' or 'of the same quality as' Whiteness; they have the samo quality that whiteness has 15

Th1s last "has' was only 'gratuttous' and should be '1s." Hence, the statement is one of self-identity (at which polnt Allen would agree). However, Vlastos does not Intend to give up self-predication completely. He still sees 1t as a necessary explanation of the: passage at Phaedo 100C: "If anything else 1s beautiful, besides Beauty itself."16 He expresses it this way

Here the '1s' must express predication, not identity . . the doctrine that Beauty is (supremely) beautifur is a clar and necessary consequence of the doctrine that Beauty is (supremely) loveworthy and that nothing is loveworthy unless it is beautiful; the ldentity, 'the beautiful is the beautiful,' or 'Beauty is Beauty ${ }^{\prime}$ could not begin to capture this doctrine.17

So vlastos is only slightly giveling in to Allen's interpretation. But he does commend Allen's interpretation as.

- a splendid protest against the imputation of (unrestricted) self-predication to Plato which I was sponsoring in my 1954 paper on the Third Man, and which had been blandly accepted by many others beside mygelf and appears to be widely accepted today. 18

As I have implied in my discussion of the Frotagoras earlier (In Chapter I). I think that Vlastos' 'Pauline Predication is analoguous to cortain Forms actually combining, one could take such a passage as vlastos 
interprets it as evidence of Forms combining, therefore allowing for certain possiblo resemblances of them. There 1s, however, something important in. what vlastos says about the Form Beaut1ful. That 1s. Plato does seem to be saying something more tan simply $A$ is $A$. And an additional problem one might bring to Allen's notion of 1dentity and relational designation is that Plato does sometimes confuse the two which would seem to imply that we could take $F$ univocally. Keeping the notion that things are named after the Forms, and that the Form holds the name properly and the particular holds it commonly. isn't there just something more to "1dentity" than Allen is telling us? I think there 1s, and, again, this brings in 'communion of Forms', further, such statements of ldent1ty ('F-ness $1 \mathrm{~s} F$ ') are applicable to all Forms. An Improvement upon Allen's notion of 'Identity' might be this, when we say 2 man 15 wise we are not saying that he is perfectly wise of W1sdom 1tself, we are saylng that he is more or less wise w1th respect to the Form he 1s, as 1t were, a relational entity (a resemblance of Man) reflecting to some degree (yet dericlently) Wisáom. No matter how good his image was and no matter how much he was wise he still would not measure up to the real Man or real W1sdom. He is not completely what 1 means to be wise, that 1s, he may be a little just, a little temperant, 
but not courageous at all. He does not fit, nor no matter how hard he tries will he ever completely fit, or be, the definition of W1sdom. Wisdom is not alone in the world of Forms, it combines with others, $1 \mathrm{~s}$ what it is because of others. Although W1sdor 1s what we may f1x our thought upon, more is involved. ${ }^{19}$ Consider the 'Blft of the gods' at Philebus 16D:

-.. we ought, they sald, whatever 1t be that we are dealing with, to assume a single form and search for 1t, for we shall find $1 t$ there contalned; then, if we have la1d hold of that, we must go on from one form to look for two, if the case admits of there belng two, otherwise for three or some other number of forms.

When we say, then, that W1sdom is w18e, or Justice is just, or Beauty is beaut1ful, etc., we are saying that it combines w1th all the other necessary Forms, and 1t does so without qualification. "Beauty is beautiful" does not mean that Beauty participates in 1tself--nor that it has the attribute of Beauty. If anything, it has as its essence a certain combination of other Forms and the statement, "A is," bejng far from a mere tautology, 1dentifies the form, reinforcing the notion that the Form 1s what it is fully (1mplying a combination of other Forms, making this Form unlque). Beserblances of the Forms are more or less deficlent in the number of Forms that inake up the Form in question-ard even if they were to partic1pate in every Form necessary, they still would be a Form. 
Not on $2 y$ is there 'degrees' in participation, but between Fors and particular there is difference in kind. There is no doubt that Pleto's language suggests selfpredication, however, if this was on purpose, I can see nowhere in the Platonic corpus where Plato makes use of the notion. Quite to the contrary, I find him attemptIng to put an end to 1 with the Third Man.

Next it would be in order to give some justification for AIIen's notion of Forms as being 'exemplary' causes. Geach had some sort of a similar notion when in his formulation of the Third Man he writes, "There is a man from whom $21 i$ other men are descended"20 --'descended from' being the logical parallel of 'being made to be an F by the Form.' R. Robinson and J. D. Derniston write of Plato:

He leaves the relations between 'forms and things somewhat vague; but the 'forms' are certalrily causes of things, both in that each ' form causes the things named after it and, apparerity. in that the "form" of the Gcod helps to cause all things. The relation of a 'form to 1ts namesake is represented as that of or $3 a$ to the copy, but also as that of what is she: $\because$ in to what shares. 21

Now, just $x$ in Plato do commentators actualiy ind Forms act1r. as causes? I might mention these several passages. $n$ the sixth book of the Republic (508) and in the seventh book (I57B) PIato speaks of the Form of the Good causines the other Forms ( $I$ also find 'One' causing the other forms in the second part of the Parmenides which w1Il be discussed a little later in this chapter). At 
Hippias Major 287C-D Platos says this!

Then this--I mean Just1ce--1s a certain thing?

Certainly.

Then, too, by Wisdcm the pise are wise and

by the Good all good things good?

of course.

And these are real things since otherwise

they would not do what they do.

To be sure, they are real things.

Then are not all beautiful things beautiful

by the Beautiful?

Yes, by the Beautiful.

Which is the real thing?

Yes, for what alternative is there?

Just how this causation works 18 indeed left vague and

Plato Fas. no doubt aware of the problem when in the

Phaedo at $100 \mathrm{~B}$ he writes:

Well, sald Socrates, what I mean is this, and there is nothing new about it ... As I am going to try to explain to you the theory of causation which I have worked out for muself... I am assuming the existence of absolute beauty and goodness and magnitude and all the rest of them.

And at $100 \mathrm{C}$,

- - It seems to me that whatever else is beautiful apart from absolute beauty is beautiful because it partakes of that absolute beauty, and for no other reason.

And at 200D,

- I cling simply and stralghtforwardiy and no doubt foolishly. to the explanation that the one thing that makes that object beautiful is the pressence in 1 or association with $1 t$, in whatererway the relation comes out, of absolute Beauty. . . It is by Beauty that beautiful things are beautiful.

And further at. 100:

Then it is also by largeness that large things 
are large and, by smaliness that smalier things are smaller.

Again, the theory of aausation siven is not terribly informat1ve. Vlastos, In h1s art1cle "Reasons and Causes in the Phaedo." tries to derive some moaning from the above passages. He c1tes Eduard Zeller (Ph1losoph1c der Griechen, II, 1, 5th edition, Leipzig, 1922) as finding the Ideas to be the 'formal, efficient, and final causes all rolled into one." So too he lists Paul Shorey (What plato sa1d, Chicago: 1933) as uncovering a 'tautological logic' in place of our usual notions of cause. Vlastos himself $1 \mathrm{~s}$ in more agreement with the latter. 22 In the Phaedo at $95 \mathrm{E}$ Socrates starts on his discussion of cause. He is quite distressed that philosophers prior to himself had sought only material and mechanical causes, whereas the teleological sense of causation is the more real (99B). Socrates then takes the 'sare route" as shown in what was quoted from 100D-E. Actually, according to Vlastos what Socrates gives is not so much a cause but a reason. It is also uniniormative but it is meant to save us from having to $200 k$ into trivial matters for causes. 23 socrates goes on to give what viastos calls the clever altia.24 at 103E2. When esked "Why $1 \varepsilon \times \mathrm{F}$ " instead of naming one Form, Socrates suggests looking at a range of Forms--all related ('communion of Forms' as show in the Soph1st). 
Vlastos concludes that plato was seeking to explain physical laws with logical necessity. 25 This, now, is not altogether different from by justification that Plato ald not actually hold to 'self-predication', that is, we have one Form before us, but then must go on to other Forms necessarily involved.

It seams to me that what Socrates is suggesting at Phaedo 103E2 (and ear1l1er) is a sort of forral cause-which is not incompatible with the Timaeus $(50 \mathrm{C}-\mathrm{D})$ and Allen's 'exemplary' cause. Further, as formal causes Socrates' desired 'teleological' cause could possibly enter in. Let me first quote the Timaeus at 50C-D,

But the forms (taken here as 'shapes' or 'structures, I gather) which enter into and go out of her (space, the receptacle for the world of Becoming) are the likenesses of eternal realities modeled after their patterns in a wonderful and mysterlous manner, which we w111 hereafter investigate. For the present we have only to concelve of three natures: flrst, that which is in process of generation, secondly, that in which the peneration takes place, and thirdly, that of which the thing generated is a resemblance naturally produced. And we may liken the recelving princlple to a mother, and the source or spring to a father, and the intermediate nature to a child, and may remark further that if the model is to take every varlety of form, then the matter in which the model is fashioned w1ll not be duly prepared unless it is formless and free frorn the 1mpress of any of those shapes which 1t is hereafter to recelve from without.

God (or the Demi-urge) is found in the Timaeus myth, apart from the Forms, using the Forms as patterns for his creation--space being a ready receptacle. God might be 
thought of as being the orlginal offlcient cause of the sense world becoming as it is. The Forms are the patterms he 'looked to' when giving structure in the world of becoming. In this sense the Forms are the formal cause (or reason for, if you wish) of structured existence. The Forms appear as exemplars--more precisely, they are exemplars; the god of the Timaeus used them as his models, and it sees that we should look to them, attempting to initate the divine order in our i1ves and in our creation of artifacts. To find out what a 'good man' 13, for example, we fix our thoughts on the Forms Good and the Form Man; then we to on to other Forms to see what man 18 capable of having (what other Forms combine with Man) and what sort of goodness he can have (what other Forms combine with the Form Good that also combine with Form Man), and having a soul (which has experienced the Forms before--cf. Meno 80D, 8IC, 85C, Phaedo 65C,75, 73A, Phaedrus 249C; Republ1c 524B-C, 526B) it is natural that we reach toward the divine design. Plato did not give this 'teleological' extension in the Timaeus, but in 11 ght of what he did say, one might make some sense of Socrates' holding the view that the teleological sense of causation was somehow more real at Phaedo $99 B$.

Now, then, suppose we grant "Forms are causes," Just how are we to take this statement. Assuming that my inter- 
pretation of Forms combining with others is correct, 'cause' here would have the standin- as a Form--and rather than merely being in addition to the other Forms. 1t combines with each. Each unlque Form has as part of 1ts essence, Cause. Nowhere does Plato exactly say this--but it is Implied if one takes particulars as existing dependently on the Forms.

Assuming the above to be true, we are saved from the regress of Ryle's argument against 'exemplif1cation. 26 If '1s' is taken as 'cause' and not the usual sense of 'exemplification' we have no infinite regress.

$T$ (Tallness) causes a to be tall (a depends on $T$ ) $s$ (Shortness) causes $\underline{b}$ to be short (b depends or $s$ ) What causes $T$ and $S$ to cause a and $\underline{b}$ Nothing more than is within their natures. It 1 s the nature of $T$ and $S$ belng unqualiflediy what they are-exemplars-othat they are comblned with Cause. There is no 'cause' lying outside to do some further causing in this case. The particular stands as the dependent to the independent-merhaps getting closer and closer to what it means to be short or tall, but nerer being what it means to be short or tall. Particularg are not in the full sense 'being.'

The Second Part of the 'Parmentdes'

That some Forms necessar1Iy combine with others, is I think, found in the second part of the Parmenides. It is 
In this section that Parmenides (Plato leads the young student through an exerclse that demonstrates that the Form Theory is not so simple as it might first appear. The 'one-many' exists in the realm of the Forms as well as In the sense world and "between" Forms and particulars. There is no real separation between the one and the many on any level of existence although a 'one' (be 1 t 'The One' or a specific Form, or a specific particular) is considered 'unique.' Socrates was right at Parmenides 129D to point out that there was no puzzle in what Zeno was saying at the beginning of the dialogue (127D, that if things are many they must be I1ke and unlike). As Plato says in the Philebus (14D-E) such an argument is "commonplace" and 'chlldish." However, it is the 'one-many' in the Forms that needs to be dealt with. Plato says at Philebus $15 B-C_{1}$

Socrates: - But suppose you venture to take as your one such things as man, ox, the beaut1ful, the good, then jou have the sort of unities that involve you in dispute if you give them your serious attention and subject them to division. Protarchus: What sort of dispute?

Socrates: First, whether we ought to belleve in the real existence of monads of this sort; secondly, how we are to concelare that each of them, being always one and the same and subject nelther to generation nor dstruction, nevertheless is, to begin with, most assuredly this single unity and yet subsequently comes to be in the infinite number of things that come into being-an identical unity thus being found sinultaneousiy in unity and in plurarity. Is it torn in pieces, or does the whole of $1 \mathrm{t}$, and this would seem the extreme of impossiblilty, get apart from itself? It is not 
your questions, Protarchus, bist these questions, where the one and many are of Enother kind, that cause all manner of dissat 1spaction if they are not properly settied, and satisfaction if they are.

It is in the e1ght Hypotheses in the second part of the Parmenldes. I belleve, that Plato attempts to settle the matter and on all levels of existence. In the Philebus he summarizes the maln feature of the demonstration with his four 'kinds', the Limit, the Unlimit, the mixture, and the Cause. Again, I think, the moral of such an exercise is this, the 'one' is not not intelligible, nor can it be, Without the 'many.' and the 'many' are not intelligible, nor can they be, without the 'one.' Bow to the Hypotheses themselves.

The rirst Hypothesis (137C-142A) shows what there would not be if Just 'One' were assumed with no combination w1th other Forms--or w1th no 'predicates' in common everyday langauage. A whole list of what would not be for this 'One follows from the singular notion itself. Here are some of the possibilities, the one cannot be many, cannot be $a$ whole of parts, has no 11mits, hasno extension or shape, is nowhere (nelther in itself nor in another), is nelther in motion nor at rest, is not the same as, or different prom 1tself or another, is not like or unike itself or another, is not equal or unequal to itself or to another, cannot be, or become, older or younger than, or in 
time at, and it cannot be named or in any way known. (A name must be a different entity apart from that which has 1t--cf. the Sophist 244D.) If the 'One' taken by 1tself is unintelligible and cannot be, we must then assume 'One' in another way.

The second Hypothesis (142B-157B) is perhaps the most important of the eight for this thesis. Here it is shown what can happen if 'One 1s,' that 1s, if one has being. In this case a whole host of possibilities arise. By assuraing 'One is' a whole serles of different 'ones' is generated (numbers) and these 'ones' must also have being (so now what we call Forms, I gather), and in turn these can generate other distinct 'ones' (particulars). The entire gamut of reality is possible. Before explaining what this would be $11 \mathrm{ke}$, however, let us see oxactly how it all begins. At $143 \mathrm{~A}$ Parmenides (Plato) says:

We are saying that the one has being, that 1s why it 1s; anc it was for that reason that $a$ 'One which $1 s^{\prime}$ was seen to be a pluraltiy. As scon as the 'One' has being, it is also a pluraltiy. That 1s, One partakes of Existence or: Eristence causes the One. The cause is different from its effect, therefore we now have three things, Existence or Being (cause), Difference(other than), and one (effect)-myet all are combined. Now with those three, by a process of addition and 
multiplication we get unlinited numbers (of Forms) and each of these, in turn, is a unity and the same process can be worked upon them to yleld an unlimited plurality of other things (particulars)--infinite numbers resulting from the process of geveration must, you see, not only be 'ones' but must have be1ng.(143D-144D). And to quote from 144D,

And unity, being one, cannot be in many places at once as a whole. And $1 \mathrm{f}$ not as a whole, it must be divided into parts, only so can it be present to all the parts of belng at the same t1me.

Further from 144E:

- for nothing that $1 \mathrm{~s}$ lacks unity, and nothing that is one lacks being.

This shows that Being is an organic whole. Existence causes the one to exist, that one with Cause causes other Forms to exist, and these Forms, as unities, cause particulars. Now with a prosess of addition and multiplication becoming becomes--the 'One is' being capable of coming to be (through particulars no doubt) many things with many characteristics, some of which are theses it can have extension and shape, can be both in itself and In another, can have motion and rest (unlike Forms, particulars are 1r something else, space, cf. Plmaeus $52 \mathrm{~A}$, and are the ever moving semblances of, cr. Phaedo 83B), is the same as and different from 1tself and others, is 
both $11 \mathrm{ke}$ and unlike 1 tself and others, is equal and unequal both to 1tself and others, exists in Time, and is and $1 \mathrm{~s}$ becoming, and is not and is not bocoming, has existence or becomes (the object of cognition and the subject of discourse as Forms), comes into existence and ceases to exist (the 'sudden' or 'Instant' with particulars). Unless one admits a sort of 'causal' connection (loglcal necessity, if you w1sh), 'being'w1ll not be known nor can 1t truly be sala to be. Each specific Form must combine with Being, Unity, Difference and Sameness (at least) and each particular must be more or less capable of partaking of the above listed (extension, being in time, etc.).

In Hypothesis III (157B-159B), because of the generation of unique different 'ones' that was shown to take place in Hypothesis II, the 'One is' mey now be assumed as \& 'one-many' or a 'whole of parts.' Others are a plurality of other 'ones' by participation in the 'One which 1s.' Th1s Hypothes1s, I believe, can be applied to all levels of belng. And others can now be taken as a unity.

\section{ONE}

MANY

The one

- otiner Forms

One spec1fic Foria - Other 11kenesses (particulars)

A particular likeness - Other likenesses it has 
of the 'others" we may say this, they share in unity apart from the 'one' (1f they were not a unity or units therein, they would be nothing), abstracting their unity in thought leaves them unlimited, it is when the limlt imposes itself on the unlimited that they are 'ones' (remember Ph1lebus 27B), all that was true of the 'One' 1tself (as being) is true too of these 'ones' (Forms) as being (having contrary characters, etc.), they are both like and unlike themselves and one another, and the same for all others.

Therefore, we do not have a share of the Form Unity in us-nor do we have the whole of Form Jnity in us. We are, rather, 1imited by the Forra. The Form couses us (imposes upon us) specification. That 1s, the Form Man being a unity (combining with Form Onity) causes us to become one man. The Form Man defines what we are (in combination with Belng, Unity, and a host of other Forms). In Hypothesis IV $(1598-160 B)$ we find, if, on the contrary, we simply assume 'One' as we did in Hypothesis I, 'others' would have no unity as a whole of parts and would not even be alurality of other 'ones' possessing contrary (difrerent, distinct) characters.

We must conclude, then, that the one 1s, that communion of porms is not only possible but necessary. The last four Hypotheses deal with the not-being of particulars 
and the possible non-being of 'one."

In Hypothesis $V(160 B-163 B)$ we Iind that a some one thing which is not can be known--several characteristics about this negative unity can be known. Something which is not is that it is not (11keness) and is not what others are. Something which is not is not equal to others. It actually has a 'sort' of being; that is, we are saying something when we say 1 is is not. Further this one thing that is not can possibly come into being (and if it does, it can also pass out). Here we ind that a 'one' (taken as a particular), although it is not, something can be known about it.

In Hypothes1s VI (163B-164A) we assume the 'One' 1tself as non-being or as a non-entity. Here we lind the 'One' is equivalent to nothing; it cannot begin to exist or change, nor have any character, nor be distinct from anything, nor be the subject of discourse or the object of cognition. That 1s, whereas non-being is understandable in a particular, it is not of the 'one' itself.

In Hypothesis VII (I64B-I65E) we assume there is no 'one' taken as limit (on any level, 'being' with 'one')--in which case we would have only the appearance of $11 \mathrm{mit}$, the appearance of greatness, smallness and equality, the appearance of 11 keness and unlikeness, etc. In Hypothesis VIII (165E-165B) we assurie no 'One', 
that is, not only would there be no one but also no being. This would be complete negation. Others would be nothing, there would not even te the appearance of 'one' or 'many,' Iimit or unlimit.

In conclusions the 'One' must be (must combine with Being) and by being it is also many (Forms). And each Foril must be (must combine w1th Being, Unlty, sameness and Difference and therefore also other Forms) and by belng and belng one it is capable of being many (part1culars in space and time). We are not Not-Belng, nor completely Being; we are both, having a sort of adject1val existence, and not really separate from the unique Forms we partske of. The Third Man, has I think, been answered. 'Self-predication' does not appear in the second part of the parmenties: a necessary communion of the forms does. The Forms are not separate from particulars, together they form wholes. Speciflc Forms are not duplicated, each Form is a unique one. One does not have an infinite regress of duplicate Forms, but rather a progress of other Forms.

The Essential Bed

No treatise on the Third Man would be complete without the Essential Bed. Many who have found iew or no answers to the Third Man in the second part of the 
Parmenides have taken a retreat to the Bed found in Plato's Republic (597C), it has, in fact, been the most popular escape. Vlastos hints at 1t. Harold Cherniss draws from 1t a denial of 'self-predication,' and Cornford recognises it as a precise foreseen objection to the Third Man. 27 Here is that passage.

Now God, whether because he so wllled or because some compulsion was lald upon him not to make more than one couch in nature, so wrought and created one only, the couch which really and in itself is. But two or more such were never created by God and never Wll1 come into being. How so? he sald. Because, sald I, if he should make only two, there would again appear one of which they both would possess the rorm or 1dea, and that would be the couch that realiy is in and of 1tself, and not the other two.

As Cornforc says, "The Form, Bed, is not a bed, and it is not tirue that it has the character in the same way that individual beds have it. Rather it is the character, and there is no ground for duplicating it."28 By showing that the Form 1 s the character and that $1 t$ does not have the character, Cherniss emphasises, then Funess is not predicated of $F .29$

On the other hand, rest in such a Bed might not be so pleasant. Strang and Cohen ${ }^{30}$ see it leading to further diffculties. Strang, for example, pointis out that the Form Bed in the obove passage is tairen as a paradigm. 
It is that to which the carpenter looks when making his bed, and that to which the artist looks when making his. If Cherniss and Cornford are right, then, according to Strang, the Form Bed cannot be a paradigm. And further an infinite regress of Beds could result if one says that 1t is the character wh1ch particulars have and it is the paradigm of that character. ${ }^{31}$ Now, as for this regress, Strang is taking too l1terally (as did the young Socrates) this notion having a Form in us. But strang is not alone--so too do Cornford, Taylor and Cherniss. By saying (as Plato does not in the text, as I will show) that the Form is tho character other beds have, we elther can have no degrees of reality (something being more or less so and so) or we are back to the problem of having a whole or a share in you. Cherniss and the others would never admit to the latter so they must (unkmowingly) accept the former. If that is the case, the Form is what we have anci yet we are not paradigms and supposedls there are Forms as paradigms. So, accepting all of that, Strang is right, we can take the form that we have, add to it, the Form as paradigm, and we are right back at the Third Man Arguient (only this time with beds).

First of all 1t should be pointed out that the passage does not say that the Form is the character we have, and secondly even if one could somelow draw such a 
notion out of the passage, it should not be takken 11terally. If Cherniss, Taylor, and Comford knew this they should have gone on to explain just what they and Plato meant. As it is we are thrown back to the problems In the flrst part of the Parmenides. Strang, of course, sees the problem but not the answer. He thinks that the Form Bed must also have the character Bed to be the paradigm that it is meant to be. And of course, that can lead to an infinite regress. 32

To resolve the problem put forth by strang I think 1t is necessary to take particulars as being 'relational entities' (as Alien does and further as they need to be as shown in the second part of the parmenides), and adding the distinction between two soxts of relational entities (in this case), namely, 'visibles' and 'immanent characters." Now, the Form Bed is not just a name-nor is it a bare entity. It is a paradigm, but how? When you get out of grour bed in the morning and look at it and think how it could be a better bed, you do not say to yourself "that thing ought to be more Bed:" period (I hope). Fixing your thought upon the Form Bed, you move on to other Forws: Stability, Comfort, Neatness, Beauty, etc. These are the things that your hed sis deficient in-not in being a bed--it already is a very visible bed. What makes the Form a paradign is not that it is the bed that wo 
have (th1s is amb1guous and even if it is taken as meaning, the Form is truly the Bed and we have less than perfect beds, deficiently the yeai Bed, nothing much is being sald and infinite regress creeps in). Neither is the Form Bed a paradign because it has a bed (although it like one with all the abuse it has been getting:). The Form Bed is a paradigm precisely because lt fulfills completely, without qualification, all that is necessary to be a bed, combining with all the necessary Forms. Our beds are resemblances of the Form Bed reflecting imperfectly (or in some cases not at all) the other necessary Forms. What the passage in the Republ10 shows is that if you have a Form Bed which is truly everything a bed can be, then there cannot be another identical to it; for that which is truiy Bed has completely all that there is to have. If there were two beds they would have to share what it inears to be bed, hence, 'what it means to be bed' would be the real Bed, the Form Bed, whereas the other two would have to be relational ent1ties. Such a notion will put Marc Cohen to rest as well.

Cohen thinks that the Essential Bed contalns a var. mint because it does not establish the Iniqueness theis. All that it shows, he says, is that there cannot be more than one Form of Bed-not exget1y one. Because, suppose we add the third Bed to the other two (TMA style), we 
would have an infinite regress, and unless the argument could show how the regress can be stopped, it could not claim exactly one Form. Then, Cohen says, add that notion to the Third Man Argument and you have no forms at all: The Third Man shows that there is not exactly one Form (an Infinite number) and if the Third Bed shows that there is not more than one--nelther exactly one nor more than one--then none whatsoever. ${ }^{33}$ This argument 1s, of course, sophistic. First of all it is based upon a misreading of the Republic passage and a misunderstanding of Plato's Theory. The Third Bed Argument does show that the Form must be unique (as demonstrated above) and although the Third Men Argument is val1d (as he very vell shows), It is not val1d agalnst what Plato really thought. So it is not valid to add the two arguments together--and even If it were, this 'not exactly one' and 'not more than one' business is misleading, a mere play on words. There is no real trap. Plato escapes.

\section{Why Socrates Didn't Escape}

Plato did not need to escape the Third Man he had held the answer to such an axgument long before the Parmen1des (Repuil1c 597C, 476A; Protagoras $700-331 \mathrm{~B}$; Euthydemus 301A; Pheedo 100D), but it was not unt: the second part of the parmensdes that he actually damonstrated how the 
'one-many' is to be taken and how 'participation' works. Plato does not change his Theory of Forms after the Parmenides (cr. Theaetetus 176E, 1850, 186A-B; Repub11c 523-524, Soph1st 249C-D, 253C-254A, Ph11ebus 15A-B, 16C-E, 58C-59D, 62A; Phaedrus 277A; Laws 965B-E; T1maeus 51B-52C; Seventh Letter 342D). The reason he put forth the Third Man Argument in the first part of the Parmenides and the reason he demonstrated that it does not work in the second part is this, I thinks Plato did not have a readymade language for his Theory of Forms ${ }^{34}$ ano using existing language was confusing, those who had some acqualntance with hia theory tended to take it too 11 terally and were unable to escape appearances.

It is in the Cratylus (11kely written shortly after the parmenides) that Plato deals most fully with the language problem. The general gist of the problem is this, names stand to things as representations and so 1deally they should not be wholly arbritary but allowed to take on a natural resemblance; 1.e., of softness, hardness, qulckness, slowness, etc. Syllables should exhiblt these, and whereas the same syllables need not be ldentical In Ell languages, essent1al resemblance and consistency is important. However, wo do not have the 1deal language. There are several problems: 1) Our language belng a copy is naturally deficient.35 2) The originators of language 
did not see clearly that which they were trying to Imitate; they being imperfect copies themselves, were likely too far: grounded in the world of flux. Still, that whlch they created does serve to spark some recollection in us. 36 3) Language undergoes change due to pure euphory: people prefer a certain sound and therefore incorporate it into places where 1t does not belong; consistency is lost. 37 4) Names can be completely arbritary. 38 Names, of course, are only a step towards knowledge--they are instruments as show at 388C. At Theaetetus $177 D-E$, "Our alm is not to say the name, it is to consider the thing named." Again this is echoed in the Sophist $(218 \mathrm{C})$ s

At present you and I have only the name in common with regard to this creature, and the thing to which we apply the name is perhaps private to each of us, but we ougint always to agree on the thing itself by means of logol rather than on the neme whthout logs.

This 'logos' is obviously the communion of the Forms-what it means to be sometring, sind our language does reflect th1s. "Truth is not found in names but in sentences" (Sophist 263A-B). But as plato says in his seventh Letter: lenguage is weak ( $343 \mathrm{Al}$ )-othat rames and statements have a "bad nature" (343D8). It is no wonder that people have trouble with Plato's Formsmothe 'one-many' problem as well; as Plato says in the Phllebus (I5D-E): 
we get this identity of the one and the many cropping up everywhere as the result of the sentences we utter, in every single sentence ever uttered, in the past and in the present, there 1t 1s. What we are dealing with is a problem that w1ll assuredly never cease to exist; this is not its first appearance. Rather it 1s, in my view, something incidental to sentences themselves, never to pass, never to fade.

And once one thinks he has a peradox of being:

He has no mercy or his father or mother or anyone else listening to him-a little more, and he would victimize even animals, as well as human beings in general, including forelgners, to whom of course he would never show mercy provided he could get hold of an interpreter. (Philebus 25E-16A)

What sounds or appears to be a paradox-as a result of our language--is in fact not, as show by the second part of the Parmenides.

Socrates does not stop Parmenides in the Third Man Arguments (132A-B, 132D-133A) precisely because students very Iikely were not aware of the problems involved; Plato wanted to show the joung members of the Academy just what ridiculous things could follow from thoir overliteral interpretations and their irability to escape appearances. And the Third Man is the prite example (in its various forms).

once again, Plato had nothing to fear from any of the three Third Man Arguments; they arose out of the fallure to understand Plato's theorymand in turn, he used them (the 'second' and the 'thi-d') to help clesx 
the way towards a better uncierstanding.

Understanding, hoverer, does not come easily as

Plato recognizes (having tangled vilth it in the Theaetetus and the Sophist) in his Seventh Letter at $342 \mathrm{~B}-\mathrm{D}_{8}$

For everything that exists there are three classes of objects through which knowledge itself must come; the inowledge itself is a fourth, and we must put as a f'ifth entity the actual object of knowledge which is the true reality [Forms]. We have then, first, a name, second, a description, third, an image, and fourth, a knowledge of the object . . . Of all these four, understanding approaches nearest in affinity and likeness to the fifth entity, while the others are more remote from it.

Only some people have a natural affinity with the Forms and even then these people are ripe for Plato's theory only if they are also intelligent and studious. (Seventh Letter $344 \mathrm{~A}-\mathrm{B})$. Plato continues in this letter to show that 'recollection' still plays an importent role in his philosophy?

Hardly after practicines detailed comparisons of names and definitions and visual and other sense perceptions, after scrutinizing them in benevolent disputation by the use of question and answer without jealousy, as last in a rlasin of understanding of each blazes up, and the mind, as 1 t exerts all its powers to the limit of human capacity, is flooded with light. (344B-C3)

'Insight,' or 'recollection,' or 'the soul seelng through herself' is nothing readily at hand. One must Work, golng beyond mere raming (as coinmunion of the Forms insists), beyond language (as criticised in the Cratylu., 
beyond the sense impressions (stopping here was the error of the Sophists as shown in the eristic dialogues), and beyond reflection, gaining the right opinion of the relations of the Forms (where the Theaetetus and Sophist stop). Therefore, since our tools for coming to reality are defective, and we already belng defective (being but resemblances of the truly real), very few are capable of understanding reallty--very few, if any, will be able to understand Plato. As he himself says in the seventh Letter at $341 C-D$;

One statement at any rate I can make in regard to all who have written or who may write with a clalm to knowledge of the subjects to which I devote myself--no matter how they pretend to have acquired 1t, whether from my instruction or from others or by their own discovery. Such writers can in my opinion have no real acquaintance with the subject... Acquaintance with 1t must come rather after a long period of attendance on instruction in the subject itself and of close comprinionsh1p, when suddenly, 11ke a blaze kindled by a leaping spark, it is generated in the soul and at once becomes self-sustaining.

Perhaps I too have not come close; then again, perhaps I have. 
Notes

IFranc1s Cornford, Plato and Parmenides, The L1brary of Liberal Arts (New York: The Bobbs-Merrili Company, Inc., 1957), p. 93-94, A. E. Taylor, Parmentdes, Zeno, and Socrates in Philosophical studies TFreoport, New York. Books for LIbraries Press, 1968), op. 87-89, Harold Cherniss, Arlstotle's Criticism of Plato and the Academy (New York: Russell and Russell, 1962), pp. 374-375.

${ }^{2}$ See Taylor, Parmenides, Zeno, and Socrates, p. 87.

3 Taylor, parmenides, Zeno, and Socrates, p. 87.

${ }^{4}$ Cherniss, Arlstotle's Criticism of plato, p. 375.

SGregory Vlastos. "The Third Man Argument in the Parmenides,". In Studies in Plato's Metabhysics, ed, by R. E. AlIen (New York: The Humanities Press, I965), p. 242, Walter Garrison Runc1man, "Plato's Parmenides," in Studies in Plato's Metaphysics, ed. by R. E. Allen (New York: The Humanties Press, 1965), p. 319 , W. R. F. Hardie, A Study in Plato (oxfordi The Clarendon Press, 1936), pp. 96-97.

$6_{\mathrm{R}}$. E. Allen, "Participation and Predication in Plato.'s Middle Dialogues," in Studies in Plato's Metaphysics, $\epsilon d$. by R. E. Allen (New Yorks the Humanities Press, 1965), p. 50 .

7Allen, "Participation and Predication," pp. 49-50. ${ }^{8}$ Allen, "Participation and Predication," D. 50. 9Alen, "Participation and Predication," pp. 50-51. 10 Ailen, "Participation and Predication," pp. 46-47. llalien. "participation and Predication," pp. 58-59. 12 Gregory Vlastos, "The Unity of the Virtues in the Protagoras," The Review of Metaohysics, XX (March, 1972), $452-453$.

13vlastos, "The Unity of the Virtues," pp. $456-457$. 
14 viastos, "The Unity of the Virtues," pp. $446-452$. 15

Vlastos, "The Unity of the Vittues," pp. $452-453$.

${ }^{16}$ viastos. "The unity of the Virtues," p. 452.

17 Viastos, "The Unity of the Virtues," p. 456.

18 viastos, "The Unity of the Virtues," p. 457.

${ }^{19}$ I have come to to this interpretation quite independently of Charles $\mathrm{H}$. Kahn, whom I have recently discovered as presenting something quite similar. Cf. "The Meaning of 'Justice' and the Theory of Forms," The Journal of Philosophy. LXIX (October, 1972), 567-579.

20 Peter T. Geach, "The Third Man Again," in Studies in Plato's Metaohysios, ed. by R. E. Allen (New Yorki The Humanities Press, 1965), p. 272.

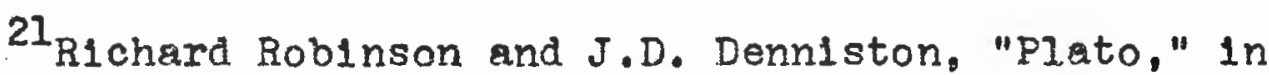
Plato I: Metaphysics and Epistemology, ed. by Gregory Vlastos, Anchor Books (Garden City, New York, Doubleday and Company. Inc., 1971), p. 9.

22 V1astos, "Beasons and Causes in the phaedo," In Plato I Metaphysics and Eplstemolosy, ed by Gregory Vlastos, Anchor Books (Garden City. New York: Doubleday and Company, Inc., 1971), pp. 132-133.

23 viastos, "Reasons and Causes," p. 156.

24 vlastos, "Reasons and Causes," p. 158.

25 viastos, "Reasons and Causes," p. 160.

${ }^{26}$ see chapter II of this thesis, pp. 75-76.

27 Vlastos, "The Third Man Argument in the Parmenides," pp. 259-260, Cherniss, "The Relation of the T1meeus to plato's Later Dialogues," in Studies in Plato's Metaphysies, ed, by R. E. Allen (New York The Humanities Press, 1965). p. 372; Corriford, Plato and Parmenides, p. 90 .

${ }^{28}$ Cornford. Plato and parmenides, p. 90.

${ }^{29}$ Cherniss, "The Relation of the Timaeus." p. 373 
30colin Strang. "Plato and the Third Man," in Plato I: Metaohysics and Eo1stemology, ed. by Gregory Viastos, Anchor Books (Garden City, Wew York: Doubleday and Company, Inc.. 1971), pp. 192-193, Marc Cohen, "The Logic of the Third Man," paper presented at a Symposium on Plato's Parmenides, Institute in Greeis Phllosophy and Sclence, Colorado College (July, 1970), pp, 2l-22.

${ }^{31}$ strang, "Plato and the Third Man," p. 193.

${ }^{32}$ strang, "plato and the rhird Man," p. 199.

${ }^{33}$ Coher, "The Logic of the Third Man,' p. 21.

${ }^{34}$ see Wilfid Sellars, Vlastos and 'Mhe Minird Man'.

in Phl losophtcal perspectites (Springtield, III. 1 Thomas. 1967). pp. 41, 47, 53. Seliars finds Plato hard-put to mold existing language to express his theory, as do $I$.

${ }^{35}$ Cratylus $430 \mathrm{~B}, 431 \mathrm{~B}-\mathrm{D}, 434 \mathrm{~A}$.

${ }^{36}$ Cratylus $411 C$. 349C-D.

${ }^{37}$ Cratylus $414 C-D$.

${ }^{38}$ Cratylus $414 \mathrm{D}$. 


\section{SOURCES CONSULTED}

Ackrill, J. I. "Plato and the Copula: 'Soph1st' 25I259." Studies in Plato's Metaphrsics. Edited by $R$. E. Allen. New York, The Humanities Press, 1965.

Allen, R. E. "Participation and Predication in Plato's Middle Dialogues." Studies in Plato's Metaphysies. Edited by $R$. E. Allen. New York: The Humanities Press, 1965.

Borges, Jorge Luis. Avartars of the Tortoise. other Inquisitions 1937-1952. New York: Washington Square Press, 1966.

Burnet, John. Greek Ph1losophy Thales to Plato. London: Macmillan, 1955.

Cherniss, Herold. Aristotle's Criticism of Flato and the Acadeny. New York: Russell anô Russe1.1, 1962.

"The Philosophical Economy of the Theory of Ideas." Plato Is Metaphysics and Fpistemoloxy. Edited by Gregory VIastos. Ancho: Books Garden C1ty, New York: Doubleday and Company, Inc.. 1971.

"The Relation of the Timaevs to Flato's Iater Dialogues." Studies in Plato's Metawysies. Falted by R. E. Allen. New York: The Humanities Press, 1965 .

Cohen, Marc. "The Log1c of the Third Vian." Paper presented at a Symposium on PIato's Parmenides, Institute in Greek Philosophy and Sclence, Coiorado College, July, 1960.

Cornford, Franc1s. Plato and Parmenides. The Library of Liberal Arts. New York: The Bobbs-Merrill Compeny, Inc., 1957.

- Plato's Theory of Inowledse. The Ilbrary of Liberal Arts. Wew Yorks The Bobbs-Merr1li Company, Inc., 1957. 
Geach, Peter T. "The Th1rd Man Again." Studies in Plato's Metaphysios, Edited by R. E. Allen. New York: The Humanities Press, 1965.

Hamilton, Edith, and Huntington, Calms, editors. The Collected Dialogues of Plato. New York: Pantheon Books, 1964.

Hardie, W. F. R. A Study in Plato. Oxford. The Clarendon Press, 1936.

Kahn, Charles 8. "The Meaning of 'Justice' and the Theory of Forms." The Journal of Philosophy. LXIX (october, 1972), 567-579.

Keyt, David. "The Mad Craftsman of the Timaeus." The

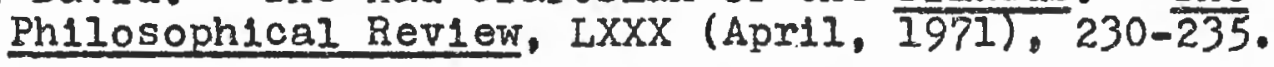

Lynch, Wilizan F. An Approach to the Metaphysics of Plato Through the 'Parmenides'. Washington Georgetow University Eress, 1959.

Moravcsik, J. M. E. "The Concept of Existence and SelfExemplification in Plato's Fhllosophy." Unpublished. Standford University.

Moreau, Joseph. "The Platonlc Idea and Its Three Fold Function: A Synthesis." International Philosophical Quarterly, IX (December, 1969), 477-517.

Owen, G. E. I. "Notes on Ryle's Plato." Ryle: Modern Studies in Philosophy. Edited by Oscar P. Wood and George Pitcher. A Doubleday Anchor original. Garden CIty, New Yorks Doubleday and Company, Inc.. 1970.

"The Place of the 'Timaeus' In Plato's Diriogues." Studies in Plato's Metaphysics. Edited by R. E. Allen. New York, The Humanities Press, 1965.

Panaglotous, Sp1ro. "Vlastos on Permenides 132AI-B2, Some of His Text and Log1c." Ph110Sophical Quarterly. XXI ( July, 1971), 255-259.

Robinson, Richard. Essaye in Greek Philosophy. Oxford, The Clarendon press, 1969. 
and Denniston, J. D. "Plato." Plato I: Metaphysics and Eplstemology Edited by Gregory Vlastos. Anchor Books. Garden C1ty, New York: Doubleday and Company, Inc., 1971.

Rochol, Hans. "The Dialogue 'Parmenides': An Insoluble Enigma in Platonism?" International Philosophical Quarterly, XI (December, 1971), 495-520.

Runoiman, Walter Garrison. Plato's Later Eplstemolog:. Cambride, England: The University Press, 1962.

"Plato's Parmenides." Studies in Plato's Metaphys10s. Edtted by . E. Allen. New Yorks The Human1ties Press, 1965.

Russell, Bertrand. Principles of Mathematics. The Norton Library. New York: W. W. Norton and Company, Inc.. n.d.

Ryle, Gilbert. "Plato's Parmenides," Studies in Plato's Metaphysics. Edited by R. E. Allen. New York: The Humaritiles Press, 1965.

- Plato's Progress. Cambridge England, The Uni versity Press, 1966.

Sellars, W1lfrld. Vlastos and "The Third Man'. Ph1losophleal perspectives. Springfield. IIIInols: Thomes, 196 ?

Strang, Colin. "Plato and the Thlrd Man." Plato I. Metaphysics and Ep1stemology. Edited by Gregory Vlastos. Anchor Books. Garden City, New York। Doubleday and Company. Inc., 1971.

Tarán, Leonardo. Parmentdes: A Text with Translation, Commentary, and Critical Essays. Princeton. New Jersey: Princeton University Press, 1965.

Taylor, A. E. Parmenides, Zeno, and Socrates. Philosophical studies. Freeport, lvew York Books for Libraries Press, 1968.

- Plato, The Man and H1s Worts. New Yorks The Hunantties Press, 1949. 
The 'Parmentdes' of plato. Oxford: The CIarendon Press, 1934 .

Turnbul1, Robert G. "Plato's Repudiatson of the "Separation of the Porms in Parmen1des 127B-135C." Unpublished.

Vlastos, Gregory. "Addenda to the Third Man Argument I A Reply to Professor Sellars." The Philosophlcal Rerlew, LXIV (July, 1955), 438-448.

"Pl.ato"s 'Th1rd Man' Argument (Farmen1des 132Al-B2): Text and Log1c." Philosophical Quarter1y. XIX (October, 1969), 289-30I.

"Postscript to the Third Han A Reply
Mr. Geach." Studies in Plato"s lletaohys1cs. Editsd by R. E. Alien. New York The Humanities Press, 1965 .

- Rassors and Causas in the Phaedo. Plato II Metaphysids ard Eplstemology Ldted by Gregory VIastos, hnonor Books. Garden City. New York Dolibleday and Company. Inc. 1971.

" "The Third Han Argument in the Parmenides." Studies in PIato's Metaphysics. Ed1ted by R. E. Allen. Wew York: The Humanities PIess, 1965.

"The Unity of the Virtues in the Protagoras." The Review of Metaphysics, XX (March, 1972). $452-453$.

Wedbers. Anders. Plato's Phllosophy of Mathematics.

Stookholm: Almqvist \& Wikseil, 1955. 